\title{
An exploratory model study of sediment transport sources and deposits in the Bohai Sea, Yellow Sea, and East China Sea
}

\author{
Changwei Bian, ${ }^{1}$ Wensheng Jiang, ${ }^{1}$ and Richard J. Greatbatch ${ }^{2}$ \\ Received 15 May 2013; revised 25 September 2013; accepted 3 October 2013.
}

[1] A regional ocean circulation model (ROMS) is used to simulate the Chinese landderived sediment transport in the Bohai Sea, Yellow Sea, and East China Sea (BYECS). The model includes the effect of currents, tides, and waves on the sediment transport and is used to study the pathway and dynamic mechanisms of the fine-grain sediment transport from the Huanghe River (Yellow River), the Old Huanghe Delta, and the Changjiang River (Yangtze River) in the BYECS. The seasonal variability of the sediment transport in the BYECS and the sources of the Yellow Sea Trough mud patch, the mud patch southwest of Cheju Island, the mud patch offshore from the Zhejiang and Fujian provinces and the Okinawa Trough mud patch are discussed. The results show that the Huanghe River sediment can be transported to the Yellow Sea Trough, but little makes it to the outer shelf while the Old Huanghe Delta sediment is mainly transported to the Yellow Sea Trough. Most of the sediment from the Changjiang River mouth is carried to the mud patch off the coast of the Zhejiang and Fujian provinces but with part of this sediment also transported to the Yellow Sea Trough. The model shows that it is difficult to transport land-derived sediment to the Okinawa Trough mud patch under normal conditions. The model also has difficulty accounting for the deposition of sediment in the region to the southwest of Cheju Island and offshore from the Zhejiang and Fujian provinces, an issue requiring further study.

Citation: Bain, C., W. Jiang, and R. J. Greatbatch (2013), An exploratory model study of sediment transport sources and deposits in the Bohai Sea, Yellow Sea, and East China Sea, J. Geophys. Res. Oceans, 118, doi:10.1002/2013JC009116.

\section{Introduction}

[2] Observations of bottom sediment distribution (Figure 1) in the Bohai Sea, Yellow Sea, and East China Sea (BYECS) show that, in addition to the mud patches in the Huanghe River (Yellow River), the Old Huanghe Delta, and the Changjiang River (Yangtze River) regions, mud patches are also found in the Yellow Sea Trough, offshore from the Zhejiang and Fujian provinces, southwest of Cheju Island and in the Okinawa Trough [Saito and Yang, 1995]. Relic sands cover the continental shelf [Emery, 1968], and the terrestrial sediments find it hard to accumulate in the sandy areas [DeMaster et al., 1985]. So how can we explain the formation of the mud patches in this region? The sources and transport mechanisms of these mud patches have been widely studied over the past decades and various plausible sediment transport mechanisms have been proposed to explain the existence of these mud

\footnotetext{
${ }^{1}$ Key Laboratory of Physical Oceanography, Ocean University of China, Qingdao, Shandong, China.

${ }^{2}$ GEOMAR-Helmholtz Center for Ocean Research Kiel, Kiel, Germany.

Corresponding author: C. Bian, Key Laboratory of Physical Oceanography, Ocean University of China, Yushan Road 5, Qingdao, 266003, China. (bianchangwei@ouc.edu.cn)
}

(C)2013. American Geophysical Union. All Rights Reserved. 2169-9275/13/10.1002/2013JC009116 patches. However, due to the lack of sufficient field data, the sediment transport mechanisms are still unclear, especially in the outer seas.

[3] The Huanghe River and the Changjiang River, which have the second and fourth largest sediment load in the world $\left(1.08 \times 10^{9}, 4.78 \times 10^{8} t / \mathrm{yr}\right)$, respectively, are the two major sources of fine-grain sediment in the BYECS [Milliman et al., 1985a; Milliman and Meade, 1983]. About $90 \%$ of the sediment discharged from these rivers is silt and clay [Wang et al., 1997], of which $70-90 \%$ of the river-load sediment is deposited as mud patches near the river mouth areas, and only $10-30 \%$ is transported beyond the coastal area [Alexander et al., 1991; Bornhold et al., 1986; Meade, 1996; Yang and Liu, 2007].

[4] The tides and wind waves have an important effect on the river mouth sediment suspension. There are strong tidal currents in the near shore area; the largest tidal current speed being more than $150 \mathrm{~cm} / \mathrm{s}$ near the Changjiang River estuary. Such currents can readily suspend near shore sediments [Larsen et al., 1985; Yuan et al., 2008b]. The tidal residual current speed is much smaller $(2-3 \mathrm{~cm} / \mathrm{s})$, but it is thought to have a significant effect on the long-term sediment transport in the BYECS [Larsen et al., 1985; Milliman et al., 1985a; Pang et al., 2004; Sternberg et al., 1985; Yanagi and Inoue, 1995]. In the BYECS, strong northerly monsoon winds dominate the winter time with an average wind speed of $5-10 \mathrm{~m} / \mathrm{s}$, while weak southerly monsoon winds generally prevail in summer with an 


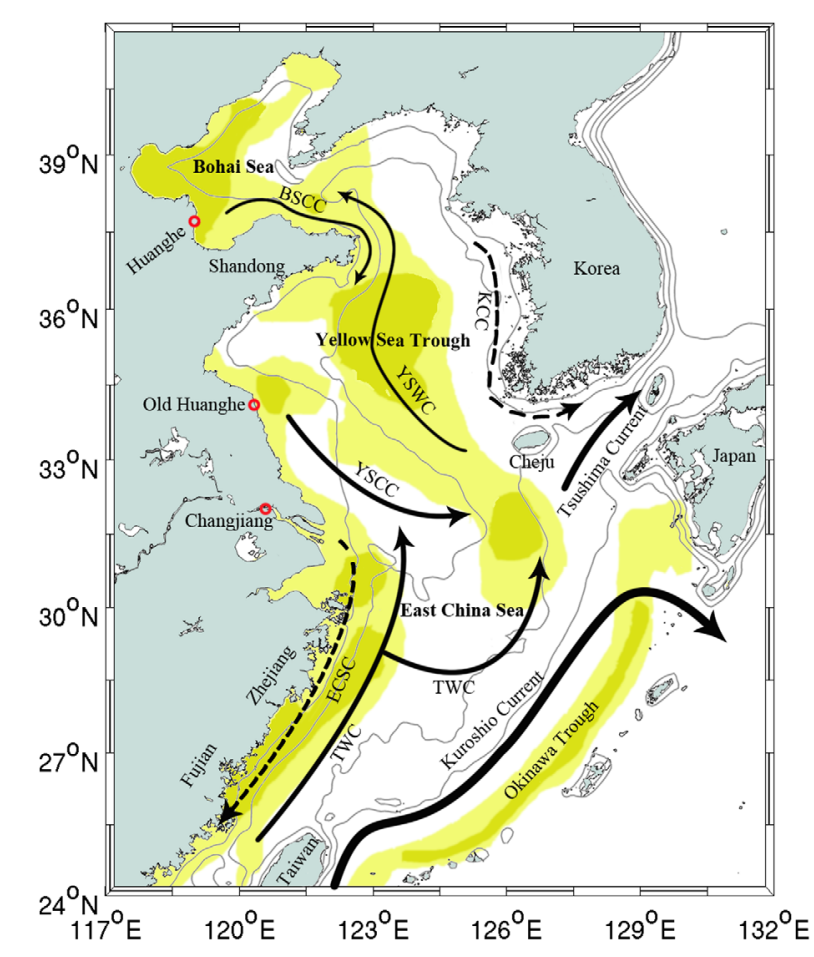

Figure 1. Schematic illustration of the topography, currents and the distribution of fine-grain particulates in the YSECS. The arrows with solid lines represent the currents that flow in the same direction in both winter and summer. The arrows with dashed lines indicate the direction of winter time currents that flow in the opposite direction in summer. These currents are: the Bohai Sea Coastal Current (BSCC), the Yellow Sea Warm Current (YSWC), the Yellow Sea Coastal Current (YSCC), the Taiwan Warm Current (TWC), the Korea Coastal Current (KCC) and the East China Sea Coastal Current (ECSCC). The yellow areas show the distribution of fine-grain sediment, with the darker colors indicating mud areas. This figure is based on the studies of Guan [1994], Yuan et al. [2008a], and Saito and Yang [1995].

average wind speed of 4-7 m/s. Wind-generated waves during the winter can induce strong bottom stresses which tend to resuspend the deposited sediment; this is an important factor for sediment resuspension in the BYECS near coastal area [Bian et al., 2010; Li et al., 2010; Wang and Jiang, 2008]. During summer, the less persistent and weaker winds cannot break down the strong thermal stratification, so most of the sediment is trapped at the sea bed.

[5] The subtidal currents play a significant role in transporting the river mouth sediment to the outer seas. Figure 1 shows a schematic diagram of the most important subtidal currents in the BYECS. In the Bohai Sea, the Bohai Sea Coastal Current flows eastward all the year round. The circulation in the Yellow Sea in winter is characterized by the northward flowing Yellow Sea Warm Current in the Middle Yellow Sea and the southward flowing Yellow Sea Coastal Current and Korea Coastal Current along the coasts of China and Korea. In summer, the Korea Coastal Current flows northward and the other two currents are too weak to be observed in the Yellow Sea. The major currents in the
East China Sea are the Kuroshio Current, the Taiwan Warm Current, the Tsushima Current and the East China Sea Coastal Current. The Kuroshio Current, which is the most distinctive feature in the East China Sea, is a strong and persistent western boundary current with high surface current speed around $100 \mathrm{~cm} / \mathrm{s}$ and less than $100 \mathrm{~km}$ in width. The Taiwan Warm Current, which originates from the Kuroshio Current intrusion water and the Taiwan Strait water splits into two branches around $28.5^{\circ} \mathrm{N}$, one branch continuing to move to the north as far as the Changjiang River estuary area, while the other turns east, first onto the outer shelf and then flows northeast near the continental slope area [Guo et al., 1987; Pan et al., 1987a, 1987b]. The Tsushima Warm Current starts from the East China Sea and flows through Tsushima Strait with a current speed in the range $20-95 \mathrm{~cm} / \mathrm{s}$, higher in summer, lower in winter. The East China Sea Coastal Current is strong and flows southward with a current speed of $10-30 \mathrm{~cm} / \mathrm{s}$ in winter and flows northeastward with a current speed of 10-20 cm/ $\mathrm{s}$ in summer, and is driven by the strong southward wind in winter and weak northward wind in summer associated with the monsoon.

[6] Since the 1980s, researchers have used the observed hydrology and suspended sediment concentration (SSC) data to study the sediment transport processes in the BYECS. In winter, the strong winds disturb the Changjiang River sediment and the wind-induced East China Sea Coastal Current is thought to carry the Changjiang River mouth sediment to the coast of Zhejiang and Fujian provinces forming the offshore mud patch [Milliman et al., 1989]. The Huanghe River flowed into the Yellow Sea from 1128 to 1855 and discharged about $250 \mathrm{~km}^{3}$ of fine sediment along the coast [Liu et al., 2002], producing the Old Huanghe Delta mud patch which contributes $4.6 \times 10^{8}$ tonne sediment to the Yellow Sea annually [Huang et al., 2001]. Some researchers [Bian et al., 2010; Milliman et al., 1985b; Yuan et al., 2008a; Milliman et al., 1989] argue that in winter, the Yellow Sea Coastal Current takes the Old Huanghe Delta sediment to the East China Sea shelf forming the mud patch to the southwest of Cheju Island, while part of the sediment continues to be carried to the north by the Yellow Sea Warm Current to form the mud patch in the Yellow Sea Trough. The source and transport path for the mud patch located in the Okinawa Trough are still unclear. Some researchers conclude that the strong southward winter monsoon resuspends the inner shelf sediment and produces cross-shelf bottom flows to transport this sediment to the Okinawa Trough mud area $[H u, 1995$; Peng and Hu, 1997; Yanagi et al., 1996], while the opponents point out that the offshore sediment transport from the Changjiang River and the coast of the Zhejiang and Fujian provinces is impeded by coastward bottom flows associated with the Taiwan Warm Current [Guo et al., 2002; Liu et al., 2007; Milliman et al., 1989; Yuan et al., 2008a]. Theoretical arguments [Condie and Sherwood, 2006] also suggest that the wind-induced cross-shelf sediment transport cannot reach the Okinawa Trough.

[7] Sedimentological, mineralogical, and geochemical studies have also attempted to determine the sources for the outer sea mud patches. Sediment samples in the Yellow Sea Trough mud patches show that the mineral content of the fine-grain sediment in the Yellow Sea Trough is similar 
to that of Huanghe River sediment, so the fine-grain sediment in the Yellow Sea Trough is probably derived from the Huanghe River [Wei et al., 2001; Qin and Li, 1986]. However, based on the clay mineral, rare earth elements and geochemical data sampled in the Southern Yellow Sea, some researchers argue that large amounts of the Changjiang River discharged sediment is also transported to the Yellow Sea mud patch areas [Cai et al., 2001; Lan et al., 2007, 2009; Wang et al., 2001]. The outer shelf muds south of Cheju Island contain calcite in their clay fraction, which means that the fine-grain sediment in this mud patch is from the Huanghe River, not the Changjiang River [Milliman et al., 1985b]. The mineral content analysis of the Huanghe River, the Changjiang River, and the outer East China Sea suggests that the fine-grain sediment in the Okinawa Trough is mainly derived from the Changjiang River [Yuan et al., 1987; Lin et al., 2003].

[8] Even today, there is a lack of high time-space resolution sediment field data in the BYECS. On the other hand, increased computational resources allow the possibility of using numerical models to simulate the sediment transport in the BYECS and answer some of the questions raised above. Based on a model forced only by tides, Dong et al. [1989] argue that the tide plays the main role for determining the sediment distribution in the Bohai Sea and the Yellow Sea. Zhu and Chang [2000] and Wang and Jiang [2007] also support this view by using a tidally forced sediment model. Yanagi and Inoue [1995] used a particle tracking model which considers the influence of the tides, currents, and wind waves on the sediment transport to study the winter time sediment transport in the BYECS. The currents are taken from a hydrodynamic model forced by climatological forcing from the Comprehensive OceanAtmosphere Data Set (COADS 1987) data set. The wave forcing data was taken from a wave model driven by monthly-mean surface wind data. The model results show that most of the Huanghe River sediment is trapped in the Bohai Sea, while the Old Huanghe Delta and the Changjiang River sediment is transported to the central Yellow Sea and to the south of the Cheju Island. Model results from Pang et al. [2004] suggest that it is easier for the finegrain sediment to be transported to the outer seas than the coarse-grain sediment and also that the sediment transport to the outer seas mainly happens in winter. The wind forcing data for their model are monthly mean climatological forcing from COADS 1994. A sediment transport model embedded in a wave-tide-circulation model has been used to simulate the Huanghe River sediment transport in the Bohai Sea and the Yellow Sea by Lu et al. [2011]. As in other studies, this model uses monthly mean climatological forcing from COADS and the wave module data are taken from the multiyear averaged monthly wave elements which are digitized from the Marine Atlas of the Bohai Sea, Yellow Sea, and East China Sea based on observations. The model results show transport of the Huanghe River sediment to the Southern Yellow Sea all year round.

[9] So far, most of the model studies focus on the sediment transport in the estuary and coastal areas and only a few researchers have studied the sediment transport processes on the scale of the BYECS itself. In the present study, a regional ocean model (ROMS) is used to gain insight into the fine-grain sediment transport mechanisms in the
BYECS. This is the first numerical modeling study of the long-term sediment transport processes on the scale of the BYECS that considers the influences of the tides, currents, and waves. The aim is to determine how the fine-grain sediment is transported away from the river mouths across the BYECS in an effort to understand the origin of the BYECS mud patches and the seasonal variation of the sediment transport.

\section{Model Description}

[10] ROMS is a three-dimensional, free-surface, terrainfollowing numerical model which solves the Reynoldsaveraged Navier-Stokes equations using the hydrostatic and Boussinesq assumptions. In this paper, the model domain covers the whole BYECS (Figure 2) with 5 min resolution in latitude and longitude and with 20 layers in the vertical direction. The vertical coordinate is a stretched, terrain-following (sigma) vertical coordinate with enhanced resolution near the surface and the bottom. ROMS supports a variety of vertical mixing schemes. Here the popular Mellor-Yamada Level 2.5 Turbulence Closure is used to represent the vertical mixing [Mellor and Yamada, 1982]. The time-step used for the three-dimensional (baroclinic) mode is $300 \mathrm{~s}$, while the two-dimensional (barotropic) mode uses a smaller time-step of $30 \mathrm{~s}$. The model is set to run $1,036,800$ (baroclinic) time steps (10 years) in this study.

[11] The model bathymetry is interpolated from the 1 min resolution topography data provided by the Laboratory for Coastal and Ocean Dynamics Studies, Sung Kyun Kwan University, Korea. However, this data set only

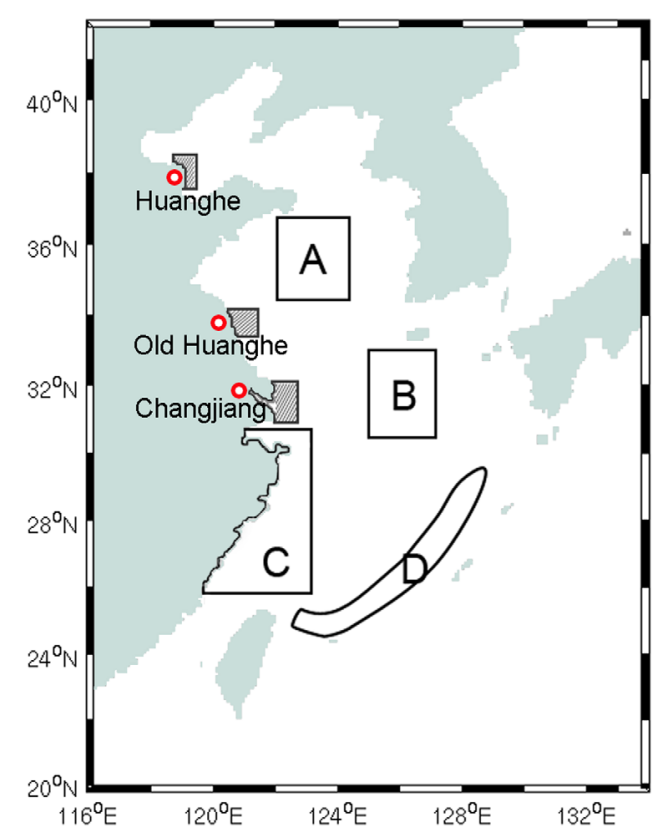

Figure 2. The model domain. The shaded areas with dark frame are the initial fine-grain sediment distribution areas. The regions A, B, C, D correspond to the Yellow Sea Trough, Cheju Island, Zhejiang and Fujian provinces and the Okinawa Trough mud patches, respectively (cf. Figure 1) and are used for the model analysis in section 3 . The light blue areas represent the land in the model. 

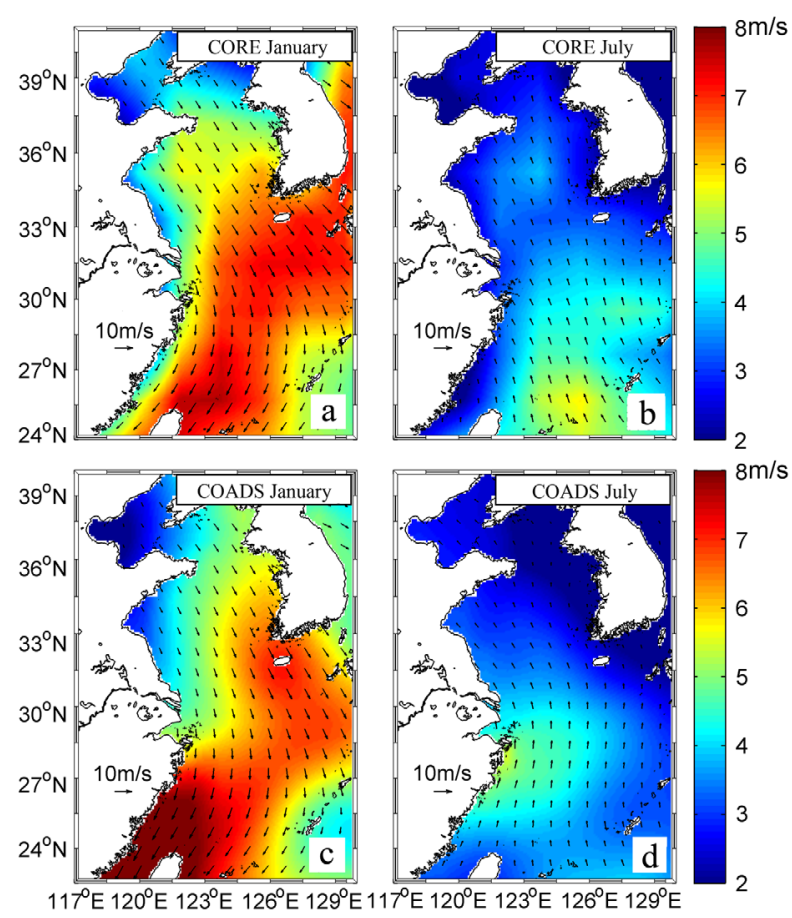

Figure 3. Monthly averaged CORE (normal year forcing) and climatological COADS wind speed in January and July (color shading). The arrows show the magnitude and direction of the monthly averaged wind in each case.

covers the area north of $24^{\circ} \mathrm{N}$ in the model domain, so the bathymetry south of $24^{\circ} \mathrm{N}$ is interpolated from the ETOPO1 data set. At the surface, the model is forced by a monthly climatology of wind stress, heat flux, and freshwater flux taken from DaSilva et al. [1994] and derived from COADS, while the bottom heat and freshwater fluxes are set to zero. The use of climatological forcing is common in previous model studies and is shown here to capture the large-scale circulation features of the BYECS and their seasonal behavior. Nevertheless, it should be noted that climatological wind stress cannot capture episodic events such as winter storms and summer typhoons, which are known to transport large amounts of sediment over short time periods [Bian et al., 2010; Condie et al., 2009; Yang et al., 2007]. The model has also been run using 6 hourly forcing from the ERA40 and NCEP reanalyses. However, in these runs the Yellow Sea Warm Current (see Figure 1) disappears. We therefore prefer to use climatological forcing in this study. The eight principal tidal constituents $\mathrm{M} 2, \mathrm{~S} 2, \mathrm{~N} 2, \mathrm{~K} 2, \mathrm{~K} 1, \mathrm{O} 1, \mathrm{P} 1$, and Q1 in the BYECS are used as tidal forcing in the model, and the tidal data are derived from the Global Inverse Tide Model data set [Egbert and Erofeeva, 2002]. At the lateral open boundaries, horizontal sea water velocity and sea surface elevation are specified from climatology obtained from the SODA data set [Carton and Giese, 2008] together with climatological potential temperature and salinity assembled from the World Ocean Atlas 2005 (WOA05) data set [Antonov et al., 2006]. The model is initialized on 1 January 2000 from a state of rest with the temperature and salinity specified from the World Ocean Atlas 2005 (WOA05).

[12] ROMS also requires wave forcing data. Here these are derived by running the Simulating WAves Nearshore
(SWAN) [Booij et al., 1999] wave model offline. The SWAN model uses 6 hourly wind derived from the Common Ocean-ice Reference Experiments (CORE) Normal Year Forcing Data [Large and Yeager, 2009] to calculate the wind-induced wave height, wave direction, and bottom wave period in the BYECS and outputs these instantaneous wave data 6 hourly. The ROMS wave module uses these wave data to calculate the near-bed orbital velocity and the wave-current shear stresses which have influence on sediment resuspension. It should be noted that the Normal Year forcing includes synoptic atmospheric forcing representative of a normal year and is used as part of the CORE forcing protocol [see Griffies et al., 2009]. The use of synoptic atmospheric forcing for the wave model gives a better representation of the waves and associated bottom stress than would be provided by using climatological monthly mean forcing to drive the wave model. As a check, monthly averaged CORE wind speed in January and July (Figures $3 \mathrm{a}$ and $3 \mathrm{~b}$ ) were calculated to compare with the climatological COADS wind speed (Figures $3 c$ and $3 d$ ). The CORE and COADS wind speed distribution patterns are similar in the BYECS. Both the wind products show strong northerly winds in January and weak southerly winds in July. There are also some differences, for example, the strongest COADS wind speed in July is found near the East China Sea coastal area while the strongest CORE wind speed in July is found in the outer East China Sea.

[13] In the sediment module, three sediment particle classes (clay, silt, and fine sand) are analyzed. Parameters used for the three sediment classes are listed in Table 1. The estimation of sediment parameters is based on the formulae from Mehta and McAnally [2008]. The critical erosion stress for each sediment class is based on the Sediment-Transport Applets from USGS (http://woodshole. er.usgs.gov/staffpages/csherwood/sedx_equations/sedxinfo. html). Clay and silt are the dominant components of the BYEC mud patches and the model analysis focuses on these classes. The model also simulates the evolution of a layered bed. The initial suspended-sediment mass in the hydrodynamic model cells is zero. The depositedsediment is represented by the sediment bed, which is a three-dimensional array with user defined constant layers (two bed layers are used here, with initial bed thickness $0.2 \mathrm{~m}$ (upper layer) and $10 \mathrm{~m}$ (lower layer) in this model case) beneath each horizontal hydrodynamic model cell. The bed layer thickness is modified at each time step account for erosion and deposition. Previous observations show that most of the river-discharged sediment was concentrated in the estuary area and was transported to the shelf through "deposition-resuspension-deposition"

Table 1. Parameters Used for the Three Sediment Classes, Clay, Silt, and Sand, Respectively

\begin{tabular}{lc}
\hline Sediment Parameter & Value \\
\hline Median grain diameter & $0.0039,0.015,0.2(\mathrm{~mm})$ \\
Grain density & $2650.0\left(\mathrm{~kg} / \mathrm{m}^{3}\right)$ \\
Particle settling velocity & $0.1,0.4,15.3(\mathrm{~mm} / \mathrm{s})$ \\
Surface erosion rate & $0.00002\left(\mathrm{~kg} / \mathrm{m}^{2} / \mathrm{s}\right)$ \\
Critical shear stress for erosion & $0.02,0.07,0.16\left(\mathrm{~N} / \mathrm{m}^{2}\right)$ \\
Porosity & 0.4 \\
\hline
\end{tabular}



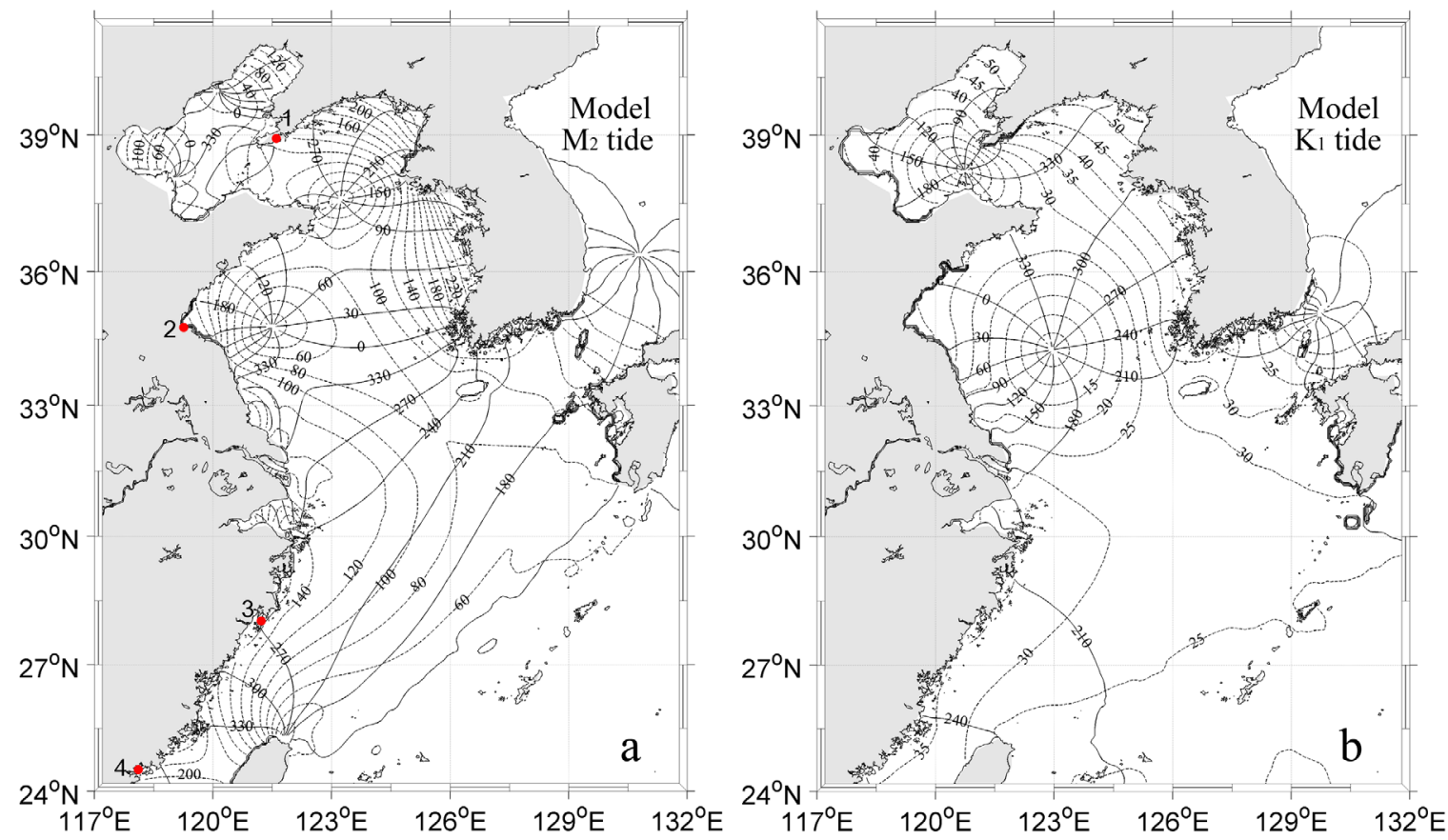

1. Laohutan $(r=0.87)$

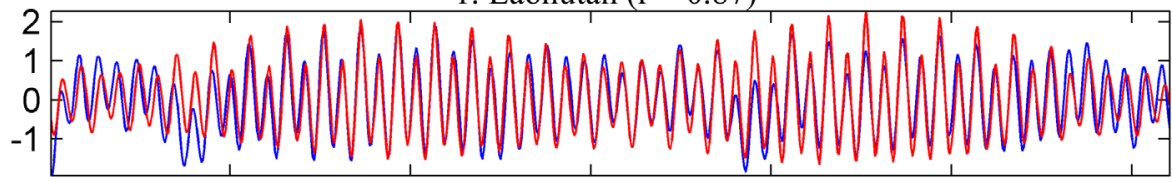

2. Lianyungang $(r=0.89)$
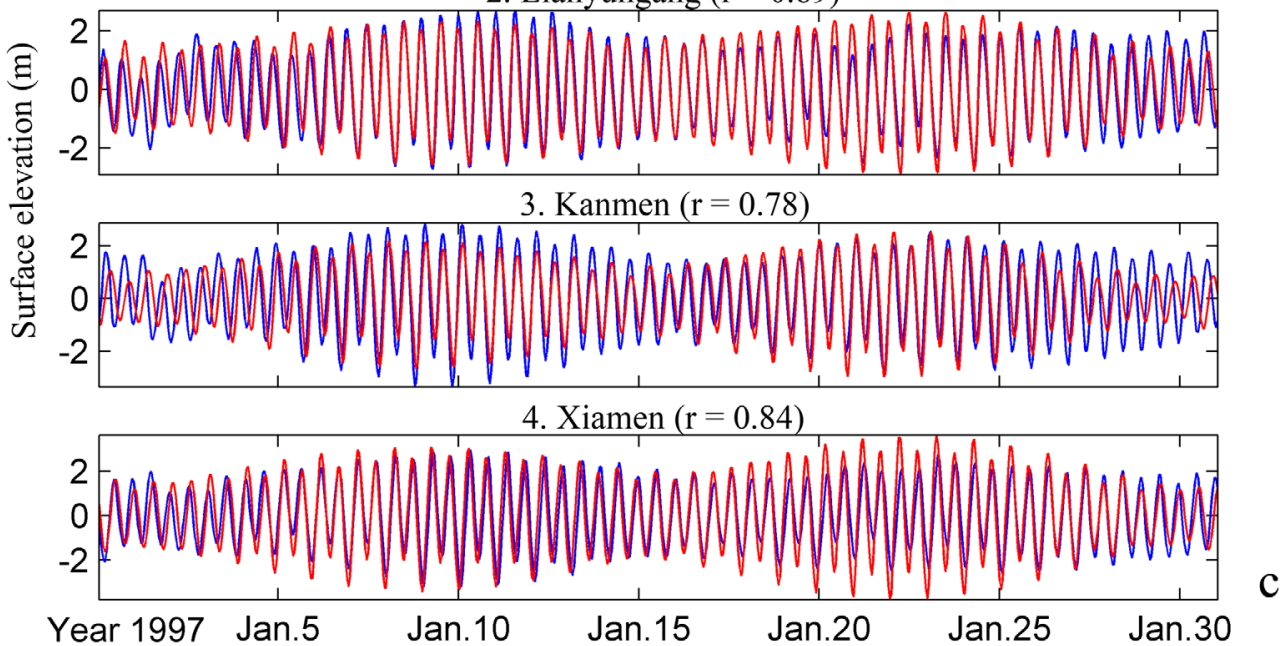

Figure 4. (a) M2 and (b) S2 tidal charts from the numerical model. Solid line: phase-lag (in deg.), dashed line: amplitude (in cm). Map c shows time-series comparing measured tides (blue line) with tides from model (red line) at four locations (numbered and shown by red dots on the map a) and their linear correlation (r).

processes by the action of the subtidal currents [Bian et al., 2013a]. No attempt is made here to model the estuaries themselves, so no river inputs have been included in the model. Rather, initially, the clay and silt deposited-sediments are placed only at the mouth areas of the Huanghe River, the Old Huanghe Delta, and the Changjiang River as shown in Figure 2 with a 0.5 fraction each (that is $50 \%$ clay and $50 \%$ silt). The initial sediment in the Huanghe and Changjiang River mouth areas repre- sents river-discharged sediment in the model, and it should be noted that the rivers from the Korean Peninsula and Taiwan Island are not considered in this work. Furthermore, the sediment module is not run to an equilibrium state but rather is run as an initial value problem in order to study the basic transport mechanisms from the river mouths to the mud patches. Fine sand, which represents the coarse-grain sediment in the BYECS, covers the bed over the rest of the model domain. The mass of each 

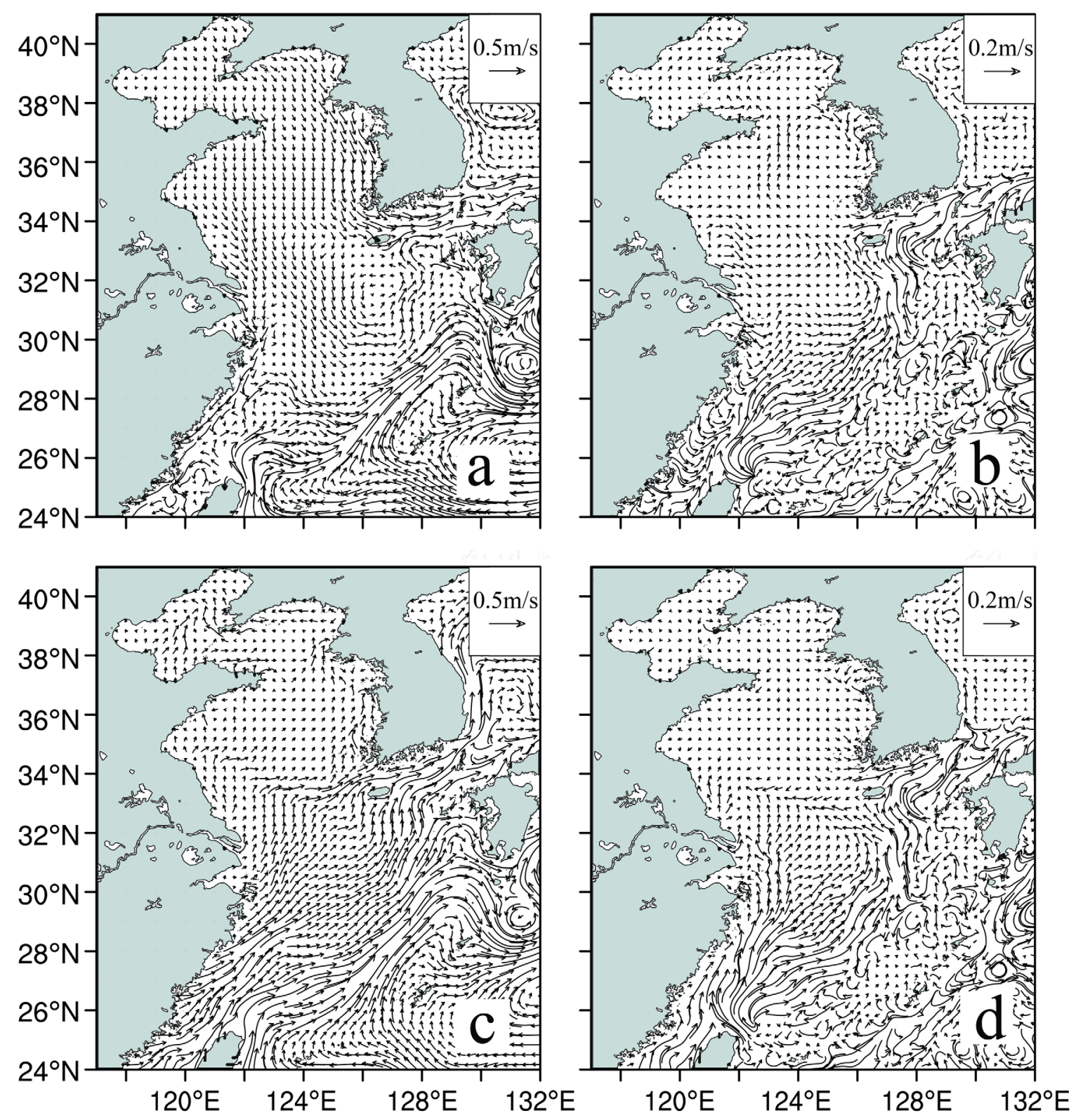

Figure 5. The model monthly mean current field. (a) January surface layer; (b) January bottom layer; (c) July surface layer; (d) July bottom layer. The vectors are sampled every four grid points.

sediment class in each bed cell is determined by the sediment density, bed thickness, bed porosity, and sediment fraction. When the calculated bottom stress exceeds the critical shear stress for erosion (see Table 1), the top bed layer deposited-sediment is suspended into the water cell at a rate given by the surface erosion rate. Likewise, the suspended-sediment in the water cell is deposited in the top bed layer at a rate depending on the particle settling velocity. Sediment is also transferred from the bottom layer to the upper layer, as required, in order to maintain a supply of sediment (particularly important in the source regions near the river mouths and the Old Huanghe Delta). The effects of the suspended sediment density on the stratification and gravitationally driven flows are considered in the model. Due to the low SSC in the most areas of the BYECS, the effects of the SSC on the reduction of the bottom shear stress and the turbulent kinetic energy are not included in the model [Byun and Wang, 2005; Wang, 2002; Adams and Weatherly, 1981]. Details of the calculation method of both the hydrodynamic model and sediment-transport module are described by Warner et al. [2008].

[14] A precise quantitative estimate of sediment transport flux cannot be made from this work, not least because the parameters for the sediment model (Table 1) have not been widely tested for their suitability in the BYECS. Therefore, the land-derived sediment is supplied in an idealized way near the river mouth and only contains finegrain clay and silt. Even though the model cannot represent the quantitative character of the sediment transport in the BYECS, a qualitative description of the fine-grain sediment transport mechanisms can be achieved from the model results. 


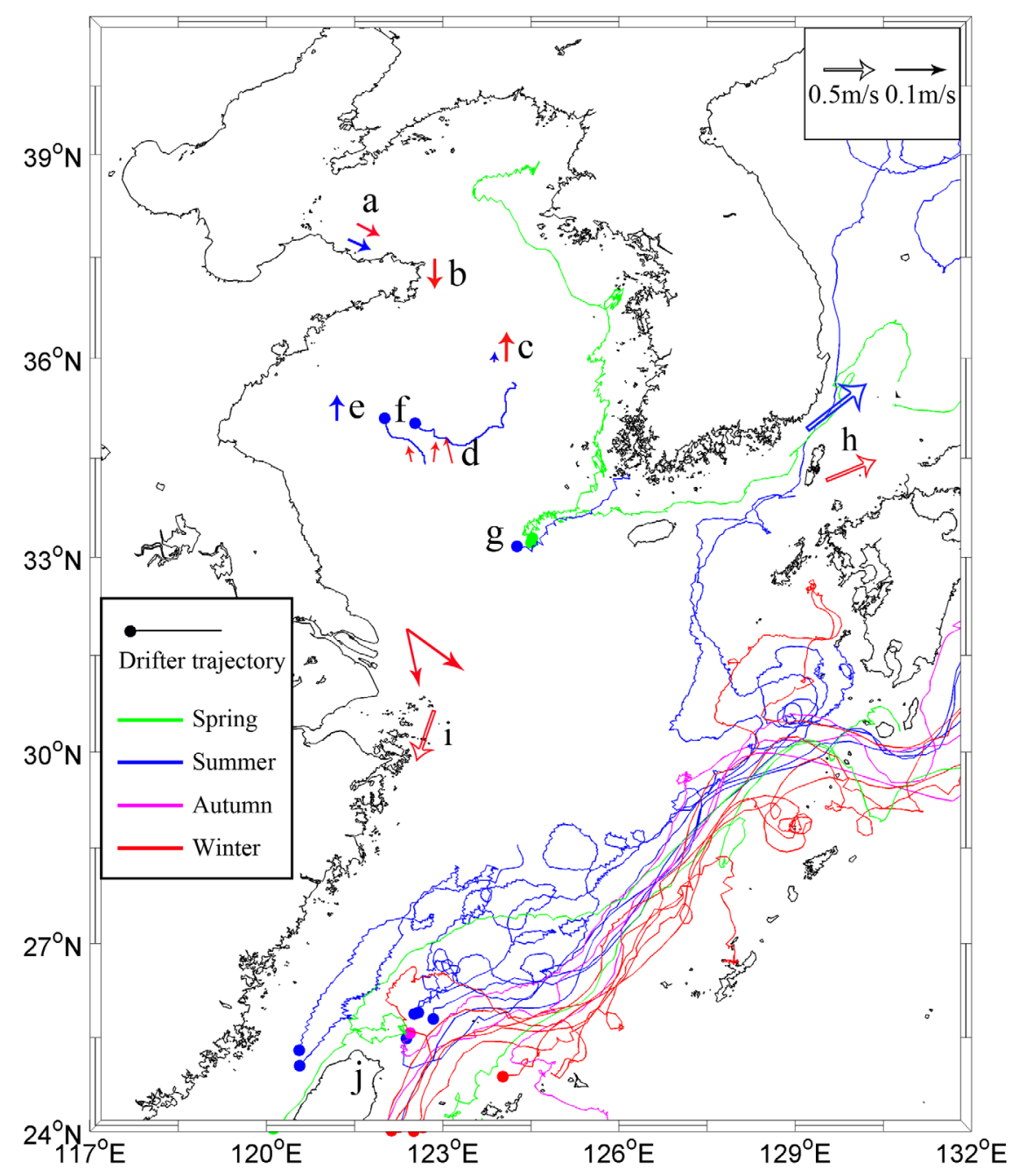

Figure 6. Available current and drifter data from the BYECS. The data number, observation method, observation layer and data source are listed in Table 2. "a-i" indicate regions referred to in the text.

\section{Model Results}

\subsection{Model Validation}

[15] The hydrodynamic model was first run with only tidal forcing in order to validate the tides. The modeled sea surface elevation results are used to calculate the harmonic constants of the M2 and K1 constituents which are the dominant diurnal and semidiurnal constituents in the BYECS (Figures $4 \mathrm{a}$ and $4 \mathrm{~b}$ ). The modeled M2 and K1 tide phase is consistent with the observed tide phase, but the modeled tide amplitude is about 10\% higher than observed. This is probably caused by the small bottom drag coefficient setting $\left(1.5 \times 10^{-3}\right)$ in the model. Sea surface elevation time-series from the model output are also compared with tide gauge measurements at the four locations shown by red dots in Figure 4 and the average correlation between the modeled and observed tides is 0.85 (Figure 4c). Even though the modeled tide amplitude is slightly high, the principal characteristics of the tides are well produced in the model.

[16] We now turn to model results generated using the complete suite of forcing. Figure 5 shows the 10 year averaged January (represents winter) and July (represents summer) monthly horizontal velocity in the surface and bottom layers of the model. The subtidal currents in the BYECS are very complicated due to the influence of the wind, intrusion water of the Kuroshio Current, the nonlinear effect of the tides, the river water input, and the topography. Even though lots of observations have been done since the beginning of the 20th century, there are only some schematic diagrams like Figure 1 to show the most basic features of the current in the BYECS [Guan, 1994]. Previous results (Figure 6) deduced from the drifter trajectories, Acoustic Doppler Current Profilers (ADCP) and current meter are used to validate the model results. A comparison between Figures 4 and 6 shows that the important currents are generally simulated well in this model, as discussed further below.

[17] The observed Bohai Sea Coastal Current flows eastward along the Shandong Peninsula all the year round (Location a in Figure 6). In the model, the Bohai Sea Coastal Current flows into the Yellow Sea along the Shandong Peninsula coastline with current speed $3-15 \mathrm{~cm} / \mathrm{s}$. In winter, the Bohai Sea Coastal Current is stronger and turns 
Table 2. The Data Used to Produce Figure 4

\begin{tabular}{llll}
\hline Number & $\begin{array}{c}\text { Observation } \\
\text { Method }\end{array}$ & \multicolumn{1}{c}{$\begin{array}{c}\text { Observation } \\
\text { Layer }\end{array}$} & \multicolumn{1}{c}{ Source } \\
\hline a & $\begin{array}{c}\text { Collected } \\
\text { field data }\end{array}$ & Surface & Guan et al. $[1994]$ \\
b & $\begin{array}{c}\text { Collected } \\
\text { field data }\end{array}$ & Surface & Guan et al. [1994] \\
c & ADCP & Bottom & Teague and Jacobs \\
& [2000]
\end{tabular}

southward around the Shandong Peninsula into the South Yellow Sea both in the model and the observations (Location $\mathrm{b}$ in Figure 6).

[18] ADCP results show that there is a year-round northward Yellow Sea Warm Current in the bottom layer of the Yellow Sea Trough with current speed around 3 $\mathrm{cm} / \mathrm{s}$ in winter and around $0.5 \mathrm{~cm} / \mathrm{s}$ in summer (Location $\mathrm{c}$ in Figure 6). Recent ADCP current results also show that the Yellow Sea Warm Current flows northward in the bottom layer at around $5 \mathrm{~cm} / \mathrm{s}$ in winter (Location $\mathrm{d}$ in Figure 6). The simulated Yellow Sea Warm Current flows northward at the bottom of the Yellow Sea Trough with current speed around $5 \mathrm{~cm} / \mathrm{s}$ in winter but does not exist in summer.

[19] Traditional view is that the Yellow Sea Coastal Current is stable and flows southward with current speed around $20 \mathrm{~cm} / \mathrm{s}$. However, some observation data shows that there is a northward Yellow Sea Coastal Current in summer (Location e in Figure 6). The model results show a strong southeastward Yellow Sea Coastal Current in winter. In summer, the Yellow Sea Coastal Current flows northward in the coastal area, but there is also a strong surface current that flows eastward from the west shore of the Yellow Sea to the Cheju Island. The satellite drifter trajectories in summer also show an eastward flow in the southern Yellow Sea with current speed of $8-10 \mathrm{~cm} / \mathrm{s}$ (Location $\mathrm{f}$ in Figure 6).

[20] Like the Yellow Sea Coastal Current, the Korea Coastal Current near the west coast of the Korean Peninsula has been thought to be known as a southward current all the year round. However, buoy results in summer show a stable northward Korea Coastal Current (Location g in Figure 6). The modeled Korea Coastal Current flows southward with current speed around $20 \mathrm{~cm} / \mathrm{s}$ in winter and flows northward with current speed around $10 \mathrm{~cm} / \mathrm{s}$ in summer.

[21] The comprehensive analysis of drifter data and anchored-position current data show that the Tsushima Warm Current starts from the East China Sea and flows through Tsushima Strait with a current speed of 20-95 cm/s and that the current speed in summer is stronger than in winter (Location h in Figure 6). In the model, the Tsushima Warm Current also shows the aforementioned characteristics.
[22] A ship-mounted ADCP has shown that the East China Sea Coastal Current flows southward with a current speed of $50 \mathrm{~cm} / \mathrm{s}$ in winter (Location i in Figure 6). Figure 5 shows the southward East China Sea Coastal Current in winter, while in summer the East China Sea Coastal Current merges with the Taiwan Warm Current and flows northeastward.

[23] Argo drifter trajectories have shown that in the surface layer, the Taiwan Warm Current flows northward in summer and, not surprisingly, the Kuroshio Current flows northward all the year round (Location $\mathrm{j}$ in Figure 6). The modeled Taiwan Warm Current and the Kuroshio Current are consistent with the observation results from the drifter trajectories.

[24] A comparison between the modeled SSC and the observed SSC in the BYECS shows that the modeled SSC can reproduce the principal features of the SSC distribution [Bian et al., 2013b]. The 10 year averaged sediment accumulation rate in the bed is calculated based on the deposited sediment mass in the model (Figure 7) and Table 3 lists a comparison between the modeled and observed accumulation rates in the BYECS. There is no significant difference between the modeled and observed accumulate rate in most areas of the BYECS. However, in the Fujian and Zhejiang Provinces coastal areas and the southwest of Cheju Island, the modeled sediment accumulation rate is much smaller than the observed accumulation rate. We will discuss the reasons why the sediment accumulation rate was not simulated well in these areas in the following sections.

\subsection{Sediment Transport}

[25] In the following, the evolution of the sediment in the model is first described for each of the three sources specified in the initial condition, the Huanghe River, the Old Huanghe Delta, and the Changjiang River, respectively. The contribution of each of these three sources to

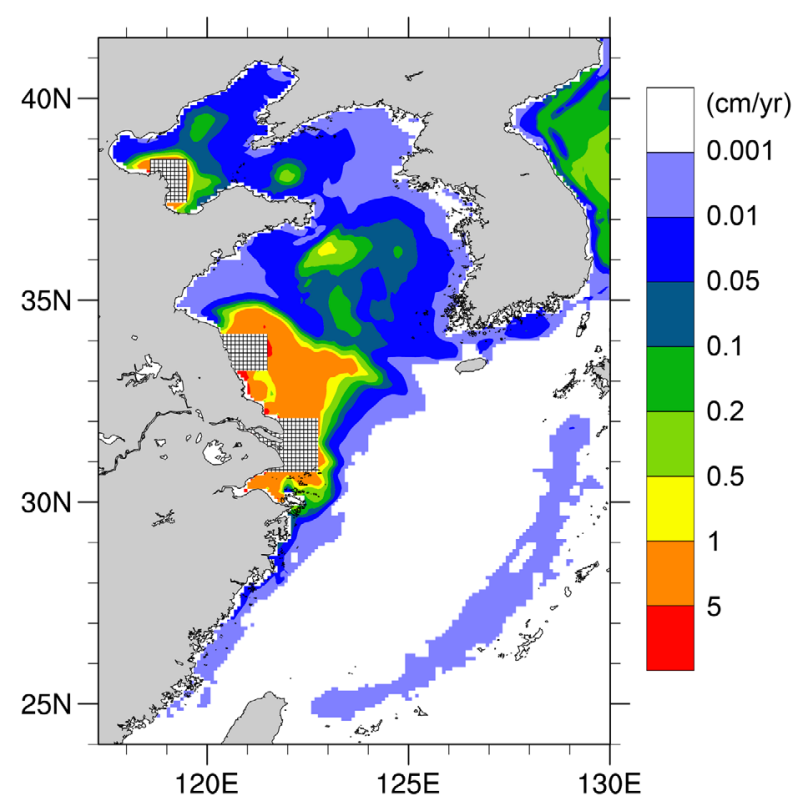

Figure 7. The 10 year averaged sediment accumulation rate $(\mathrm{cm} / \mathrm{y})$ in the model. 
Table 3. Comparison of the Modeled and Observed Sediment Accumulation Rates

\begin{tabular}{|c|c|c|}
\hline Area & $\begin{array}{l}\text { Modeled } \\
\text { Accumulation } \\
\text { Rate }(\mathrm{cm} / \mathrm{yr})\end{array}$ & $\begin{array}{l}\text { Observed } \\
\text { Accumulation } \\
\text { Rate }(\mathrm{cm} / \mathrm{yr})\end{array}$ \\
\hline Yellow River estuary & $>1$ & $\begin{array}{l}>1[\text { Li et al., } 2002] \\
1-3[\text { Wang et al., } 2006] \\
3.1[\text { Du et al. }, 1990]\end{array}$ \\
\hline Middle Bohai Sea & $0.1-0.2$ & $\begin{array}{l}<0.2[\text { Wang et al., } 2006] \\
0.18[\text { Du et al., } 1990]\end{array}$ \\
\hline Northeast of Bohai Sea & $0.01-0.05$ & $<0.2[$ Li et al., 2002] \\
\hline $\begin{array}{l}\text { North Yellow sea } \\
\text { along } 122.2^{\circ} \mathrm{E}\end{array}$ & $0.01-0.5$ & 0.07-0.45 [Qi et al., 2004] \\
\hline Middle Yellow Sea & $0.05-0.2$ & $\begin{array}{l}0.03-0.19 \text { [Alexander et al., } \\
\text { 1991] } \\
0.094-0.17 \text { [Zhao et al., } \\
\text { 1991] }\end{array}$ \\
\hline $\begin{array}{l}\text { Southwest of } \\
\text { Shandong peninsula }\end{array}$ & $0.2-1.0$ & $\begin{array}{l}0.16-0.82 \text { [Alexander et al., } \\
\text { 1991] } \\
0.3-0.6[\text { Zhao et al., 1991] }\end{array}$ \\
\hline $\begin{array}{l}\text { Changjiang River } \\
\text { estuary }\end{array}$ & $0.1-5.0$ & $\begin{array}{l}0.02-2 \text { [DeMaster et al., } \\
\text { 1985] }\end{array}$ \\
\hline Okinawa Trough & $<0.01$ & $\begin{array}{l}0.09 \text { [Chung and Chang, } \\
1995] \\
0.0021-0.0085 \text { [Li et al., } \\
1999] \\
0.01-0.04 \text { [Li et al.., 1999] } \\
0.01-0.05[\text { Li, 2007] }\end{array}$ \\
\hline $\begin{array}{l}\text { Southwest of } \\
\text { Cheju Island }\end{array}$ & $<0.001$ & $\begin{array}{l}0.02 \text { [Alexander et al., } 1991] \\
0.11-0.16 \text { [Zhao et al., 1991] }\end{array}$ \\
\hline $\begin{array}{l}\text { Fujian and Zhejiang } \\
\text { coastal area }\end{array}$ & $<0.01$ & $0.4-1.0[$ Huh and $S u, 1999]$ \\
\hline
\end{tabular}

the regions labeled A, B, C, and D in Figure 2 is then presented and the role of the seasonal cycle discussed.

\subsubsection{The Huanghe River Sediment Transport}

[26] One group of researchers concludes that most of the Huanghe River sediment is trapped in the Bohai Sea. After analyzing the Huanghe River sediment results, Meade [1996] suggested that $9 \times 10^{8} \mathrm{t}$ of sediment is deposited within the Huanghe River delta annually, and the remaining $2 \times 10^{8} \mathrm{t}$ of sediment is transported alongshore or deposited on the continental shelf, virtually all within the Bohai Sea. Martin et al. [1993] estimated the sediment flux in the Bohai Sea Strait according to current velocity and sediment concentration data and argued that less than $1 \%$ (about $6 \times$ $10^{6} \mathrm{t} / \mathrm{yr}$ ) of the Huanghe River discharge passes through the Strait. Other researchers, however, argue that a significant portion of the Huanghe River sediment can be transported to the Yellow Sea. Based on field observations and satellite-derived sediment concentration data, Bi et al. [2011] argued that the annual sediment flux through the southern Bohai Strait is about $4 \times 10^{7} \mathrm{t} / \mathrm{yr}$. Alexander et al. [1991] analyzed ${ }^{210} \mathrm{~Pb}$ sediment accumulation rates in the Yellow Sea and suggest that $9-15 \%$ of the annual Huanghe River discharge is accumulating in the Yellow Sea. Yang and Liu [2007] propose that nearly 30\% of the annual Huanghe River sediment is resuspended and transported out of the Bohai Sea into the Yellow Sea based on a study of high-resolution Chirp sonar profiles and Radiocarbon-14 dates. Sediment concentration studies also show that the Huanghe River sediment is transported to the Yellow Sea mainly in winter [Bao et al., 2010; Bian et al., 2010; Milliman et al., 1986].

[27] Figure 8 demonstrates that in the model the Huanghe River sediment extends to the northwest Bohai Sea under the effect of the Bohai Sea interior currents at the beginning of the simulation. After 7 months, a small part of the sediment is transported to the north of the Shandong Peninsula by the Bohai Sea Coastal Current. During the following winter, the Bohai Sea Coastal Current carries the sediment to the south around the tip of the Shandong Peninsula. After 10 years, a mud patch to the north and southeast of the peninsula is generated by the Huanghe River sediment. From the results, it can be concluded that the Huanghe River sediment can be transported to the South Yellow Sea by the Bohai Sea Coastal Current and form a mud patch at the Yellow Sea Trough. A small amount of sediment is also transported to the Sea of Japan (East Sea) through the Cheju Strait. However, most of the Huanghe River sediment is trapped in the Bohai Sea and the Yellow Sea.

\subsubsection{The Old Huanghe River Sediment Transport}

[28] There seems no doubt that the Old Huanghe Delta sediment is transported to the south of the Cheju Island mud patch by the Yellow Sea Coastal Current in winter [Bao et al., 2010; Bian et al., 2010; Lee and Chough, 1989; Lim et al., 2007; Milliman et al., 1986; Yanagi and Inoue, 1995; Milliman et al., 1985b], and part of it is kept moving to the central Yellow Sea by the Yellow Sea Warm Current in winter [Milliman et al., 1986; Yanagi and Inoue, 1995].

[29] Figure 8 indicates that the Old Huanghe Delta sediment is transported southward by the Yellow Sea Coastal Current in winter. After 5 months, a large amount of Old Huanghe Delta sediment is transported in the direction of Cheju Island by the southeastward Yellow Sea Coastal Current and a small part of the sediment reaches the west of Cheju Island. Satellite observations also show the turbid water plume that extends from the Old Huanghe Delta into the central East China Sea from autumn to the next spring [Yuan et al., 2008a; Wang and Jiang, 2008]. Instead of being deposited to the west of Cheju Island, most of the sediment in the model is delivered to the Yellow Sea Trough by the Yellow Sea Warm Current in winter and delivered to the Sea of Japan by the Tsushima Warm Current all the year round. After 10 years, a mud patch containing the Old Huanghe Delta sediment has formed in the Yellow Sea Trough although some of the sediment has continued to move to the north and has been deposited in the Bohai Sea. The sediment which is transported to the Sea of Japan by the Tsushima Warm Current also forms a mud patch there. The analysis of sediment minerals and sediment flux in the Sea of Japan demonstrates that the East China Sea outer shelf sediment can be carried to the Sea of Japan by the Tsushima Warm Current [Otosaka et al., 2004; Hong et al., 1997; Aoki et al., 1974]. It can be concluded that the Old Huanghe Delta sediment can be transported to the central Yellow Sea as in the traditional views described before. However, the Old Huanghe Delta sediment cannot be deposited to the southeast of the Cheju Island in the model. The reason for this discrepancy will be discussed in section 3.2.3. 

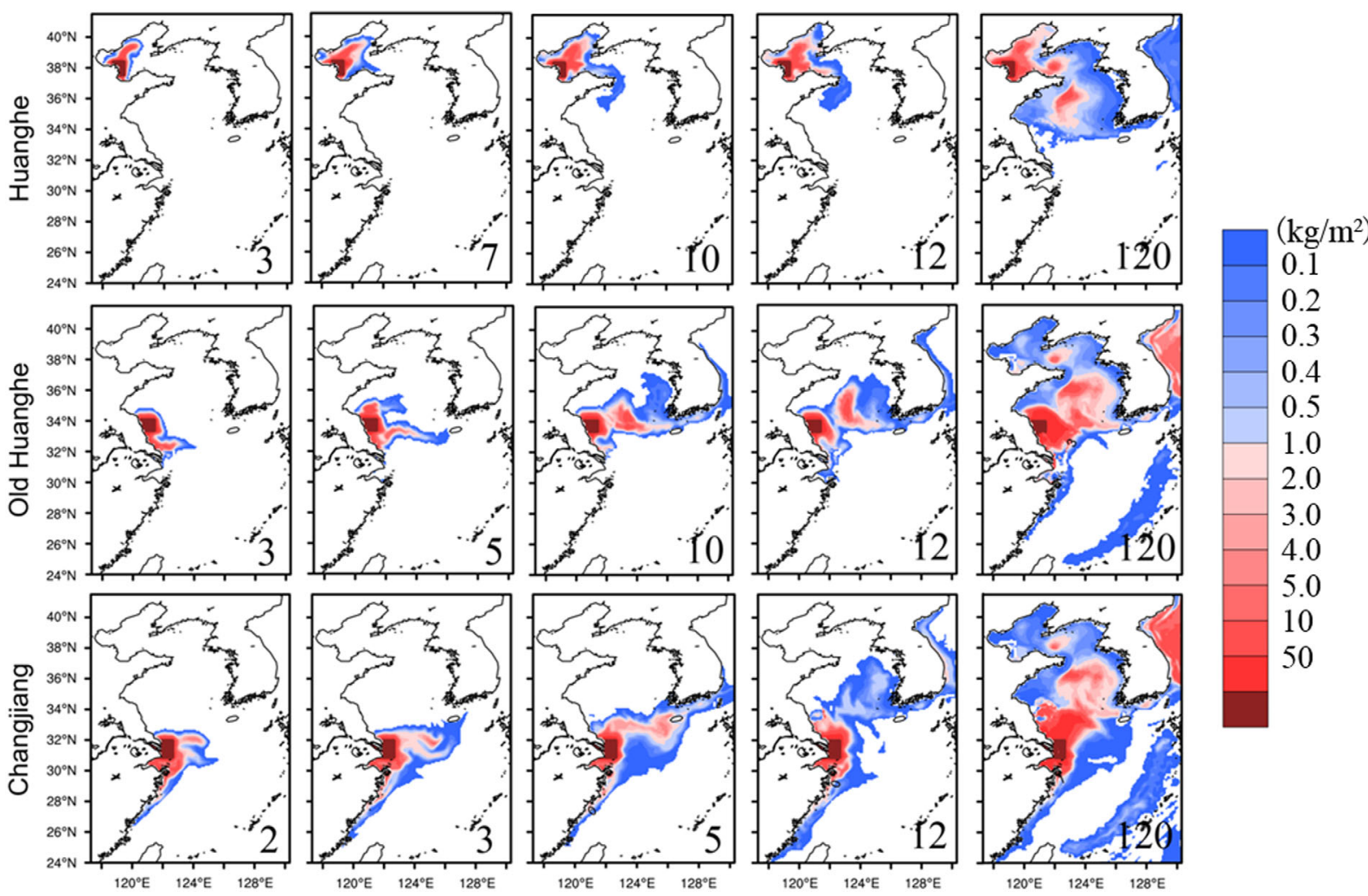

Figure 8. The model-simulated deposited sediment mass per square meter at the end of the months, blank areas denoting mass density less than $0.01 \mathrm{~kg} / \mathrm{m}^{2}$. The model is initialized on 1 January 2000 and the numbers represent the model run time (in months).

\subsubsection{The Changjiang River Sediment Transport}

[30] Most researchers argue that the Changjiang River sediment is carried to the coast of the Zhejiang and Fujian provinces by the East China Sea Coastal Current and that the seaward transport of the Changjiang River sediment is blocked by the Taiwan Warm Current [Guo et al., 2002; Liu et al., 2007; Milliman et al., 1986, 1989; Wang and Jiang, 2008; Yuan et al., 2008a; Xu et al., 2012].

[31] In the present model results, there are two paths for the fine-grain Changjiang River sediment transport in winter and spring (Figure 8). One part of the sediment is delivered to the south coastal area by the East China Sea Coastal Current and another part of the sediment is carried to the southwest of the Cheju Island by the Yellow Sea Coastal Current and deposited there during the first 5 months of the model integration. However, the Changjiang River sediment which has been deposited to the southwest of the Cheju Island cannot stay there for long. The deposited sediment is resuspended and kept moving to the Yellow Sea Trough and Sea of Japan by the Yellow Sea Warm Current and the Tsushima Warm Current. It is still unclear what the dynamic mechanisms are for forming the mud patch southwest of Cheju Island. Hu [1984], Pang and Hu [2002], and $Q u$ and $H u$ [1993] pointed out that a counterclockwise eddy or gyre accompanied by upwelling will converge the bottom sediment to the eddy center, so that the upwelling plays the determinant role for forming the mud patch in this region. However, Yanagi et al. [1996] argue against this view based on the observation of clockwise circulation at the bottom in this region. In spite of the uncertainty of the dynamic mechanisms supporting the mud patch, there is no doubt that a large amount of land-derived sediment accumulates in this area in reality. The modeled wavecurrent interaction bottom shear stress in this area is relatively weak (about $0.1 \mathrm{~N} / \mathrm{m}^{2}$ ), which can provide a suitable environment for the deposition of sediment. However, the cohesive and consolidation characteristics of the fine-grain sediment are not considered in the sediment module, so the critical shear stress for erosion is small (Table 1), which means that the sediment cannot be permanently deposited to the southwest of the Cheju Island in the model.

[32] Turning now to the role of the Taiwan Warm Current, the traditional view indicates that there is onshore bottom Ekman transport of the Taiwan Warm Current water which blocks the seaward sediment transport [Liu et al., 2007; Sun et al., 2000; Wang and Jiang, 2008; Yang et al., 1992; Yuan et al., 2008a], and the front between the Taiwan Warm Current and the East China Sea Coastal Current prevents the coastal sediment from being transported to the shelf [Bian et al., 2013a]. However, the model results present a rather different picture: in the near shore area, the northward Taiwan Warm Current may block the seaward sediment transport, but in the shelf area, the seaward branch of the Taiwan Warm Current transports sediment to the outer continental shelf of the East China Sea. In spring, the Changjiang River sediment is transported to the east around $31^{\circ} \mathrm{N}$ and turns to the north around $127^{\circ} \mathrm{E}$ (Figure 8); the sediment transport path is the same as that of the Taiwan Warm Current (Figure 5). This means the Taiwan Warm Current carries the coastal sediment to the outer continental 

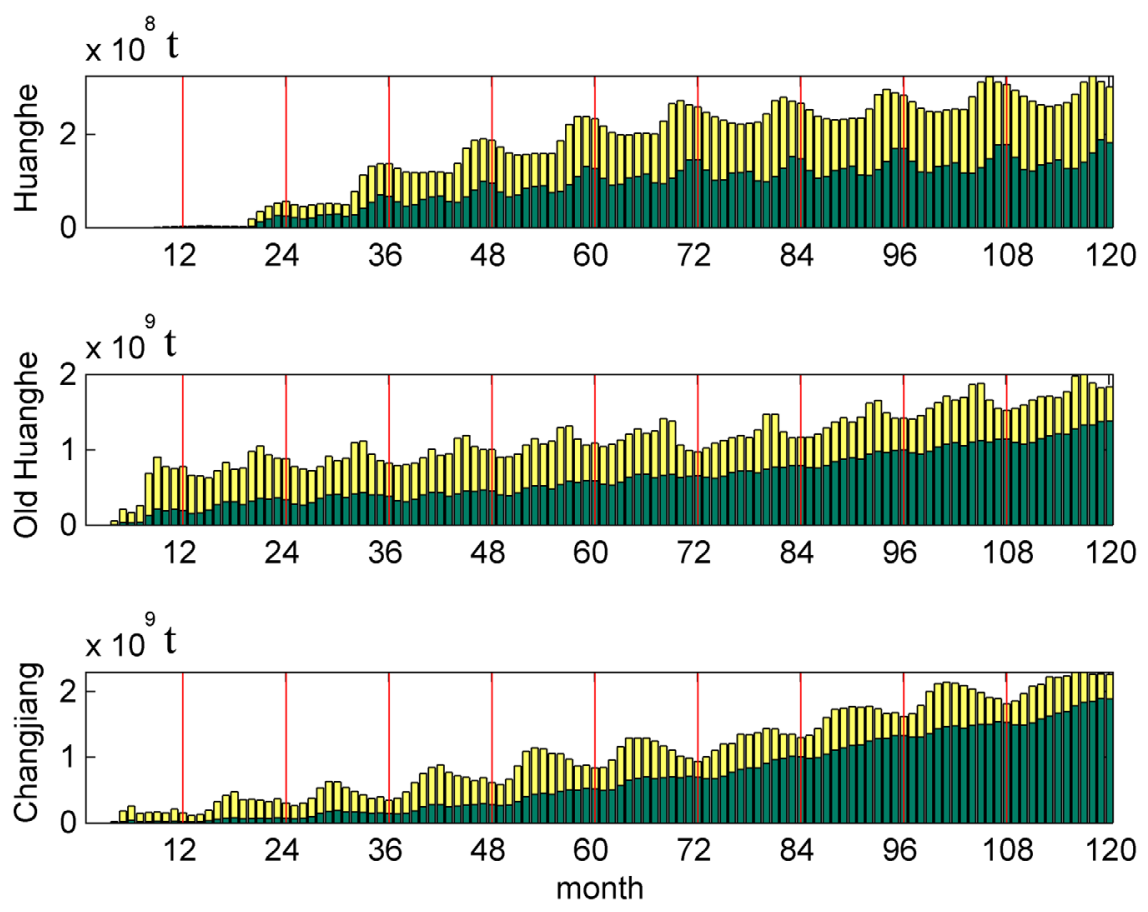

Figure 9. The Huanghe River, the Old Huanghe Delta and the Changjiang River sediment mass ( $\mathrm{t}$ ) that is deposited on the sea bed and suspended in the water column in region A of Figure 2 (the Yellow Sea Trough mud patch). The yellow represents suspended-sediment mass and the dark green represents depositedsediment mass, both at the end of each month. Note: different mass scales are used for different plots.

shelf. Part of the outer shelf Changjiang River sediment is transported to the Yellow Sea Trough in winter by the Yellow Sea Warm Current, and part of it is carried to the Sea of Japan by the Tsushima Warm Current year-round.

[33] There are two obvious factors that favor for seaward sediment transport by the Taiwan Warm Current. First, a large amount of Changjiang River sediment is transported to the mud patch offshore from the Zhejiang and Fujian provinces by the southward East China Sea Current in winter, which provides a supply of fine-grain sediment for transport. Second, from spring to summer, the southward wind attenuates and turns northward gradually leading to the development of the northward coastal current and the stronger Taiwan Warm Current which will transport the fine-grain sediment to the north and to the outer shelf. Two cruises were made in July 2006 and January 2007 in the East China Sea [Bian et al., 2010]. High turbidity was observed in the near bottom water of the Taiwan Warm Current and the turbidity is higher in summer than in winter. These observed turbidity results support our view that the Taiwan Warm Current transports sediment seaward above the bottom boundary layer instead of blocking the seaward transport. Previous studies of the sediment transport induced by the Taiwan Warm Current mainly focused on the coastal areas where the onshore bottom Ekman flows may block the seaward sediment transport. But in the shelf area, the seaward sediment transport by the Taiwan Warm Current was probably neglected in previous studies due to the lack of long-term current and sediment concentration observations.

[34] After 10 years of the model run, the Changjiang River sediment is distributed over the whole BYECS, and mud patches in the Yellow Sea Trough and Sea of Japan have been formed. There is also a small amount of sediment deposited in the Okinawa Trough area. The mechanism for forming the Okinawa Trough mud patch will be discussed in section 3.2.4. However, the fine-grain sediment does not tend to persist on the middle and outer continental shelf of the East China Sea because of the high disturbing energy in that area caused by the tide and the strong Taiwan Warm Current.

\subsubsection{Seasonal Variation of the Sediment Transport}

[35] The regions A, B, C, and D (see Figure 2) represent the Yellow Sea Trough mud patch, the Cheju Island mud patch, the mud patch offshore from the Zhejiang and Fujian provinces and the Okinawa Trough mud patch, respectively. These four regions are selected to find out the contribution of land-derived sediment to these mud areas in the model. The mass of fine-grained sediment, which includes the deposited-sediment mass in the bed and the suspendedsediment mass in the water, is used to study the seasonal variation of the fine-grain sediment transport in these regions.

[36] Most of the Yellow Sea Trough mud patch (region A) sediment is from the Old Huanghe Delta and the Changjiang River, while the Huanghe River sediment has the minimum contribution (Figure 9). The Huanghe River sediment is carried here by the strong Bohai Sea Coastal Current mainly in winter, because the winter sediment concentration is higher than summer. Previous observation studies also argue that the Huanghe River sediment is mainly transported to the Yellow Sea in winter [Bian et al., 2010; Bao et al., 2010; Milliman et al., 1986]. The Changjiang River sediment is transported here mainly in spring, 

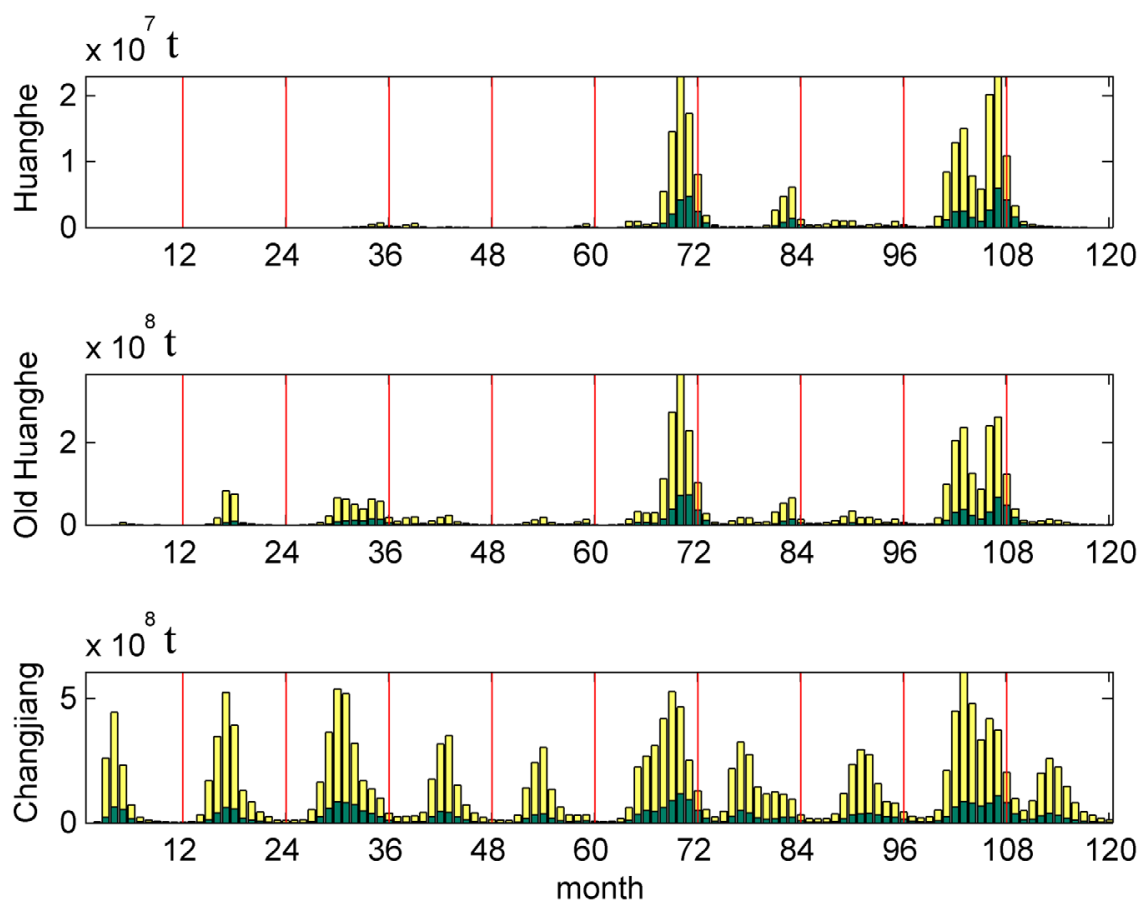

Figure 10. The Huanghe River, the Old Huanghe Delta and the Changjiang River sediment mass ( $t$ ) that is deposited on the sea bed and suspended in the water column in region B of Figure 2 (the Cheju Island mud patch). The yellow represents suspended-sediment mass and the dark green represents depositedsediment mass, both at the end of each month. Note: different mass scales are used for different plots.

because in spring the Taiwan Warm Current carries the Changjiang River sediment to the outer shelf, then the Yellow Sea Warm Current transports the sediment to the Yellow Sea mud patch.

[37] Figure 10 shows that Changjiang River sediment can reach the Cheju Island mud patch (region B) in spring, however, only a small part of the sediment is deposited there, most of the sediment moving on to the Yellow Sea Trough in winter or the Sea of Japan in summer. A smaller amount of sediment also reaches the area sporadically from the Old Huanghe Delta and a much smaller amount from the Huanghe River. Based on observed suspended matter concentration, Milliman et al. [1985a] and [1986] suggest that the Old Huanghe Delta sediment is carried to the Cheju Island mud patch mainly in winter. Satellite observations also show a winter time sediment transport from the Old Huanghe Delta to the northern shelf of the East China Sea [Sun et al., 2000; Yuan et al., 2008a; Wang and Jiang, 2008]. Figure 8 shows that the coastal sediment is transported to the southwest of Cheju Island from the Changjiang River in winter and that most of the sediment arrives at the mud patch area in spring. As noted in the section 3.2.3, even though sediment can be transported to this region, the model deposits do not persist, such that the predicted rate of deposition is lower than observed.

[38] Most of the sediment for the mud patch off the coast of the Zhejiang and Fujian provinces (region C) is supplied by the Changjiang River (Figure 11). In winter time, strong wind-induced waves stir the Changjiang River sediment at the river mouth and the southward East China Sea Coastal Current then takes it to region C. However, most of the sediment that is transported to region $\mathrm{C}$ in winter is trans- ported northward by the northward East China Sea Coastal Current in summer, in contrast to previous studies that show that most of the sediment which is transported to region $\mathrm{C}$ will deposit there instead of being transported northward in summer. This is because the tidal and subtidal currents are strong in region $\mathrm{C}$, as a result, the sediment which be transported to region $\mathrm{C}$ is easily resuspended and transported away. As for the Cheju Island mud patch (region B), due to the unfavorable depositional environment for fine-grained sediment in the model, most of the sediment cannot stay in region $\mathrm{C}$ and the modeled sediment accumulation rate is much smaller than observed. A small amount of the Old Huanghe Delta sediment is also carried to region $\mathrm{C}$ by the southward coastal current in winter. However, the Old Huanghe Delta sediment does not accumulate in region $\mathrm{C}$ year by year. Only very little Huanghe River sediment can reach this area.

[39] The strong Kuroshio Current between the outer continental shelf and the Okinawa Trough in the East China Sea effectively blocks the seaward sediment transport, so the outer continental shelf sediment cannot cross the Kuroshio Current to the trough under normal conditions [ Guo et al., 2002; Yang et al., 1992; Bian et al., 2010]. Episodic events, such as winter storms, internal-tides and turbidity flows, are capable of transporting sediment into the Okinawa Trough [Huh et al., 2006; Liu et al., 2005; Li et al., 1999, 2001].

[40] Figure 12 shows that it is difficult for the Huanghe River and Old Huanghe Delta sediment to be carried to the Okinawa Trough (region D) in this model; only a small amount of Changjiang River sediment is transported to the Okinawa Trough and it accumulates there only slowly. 

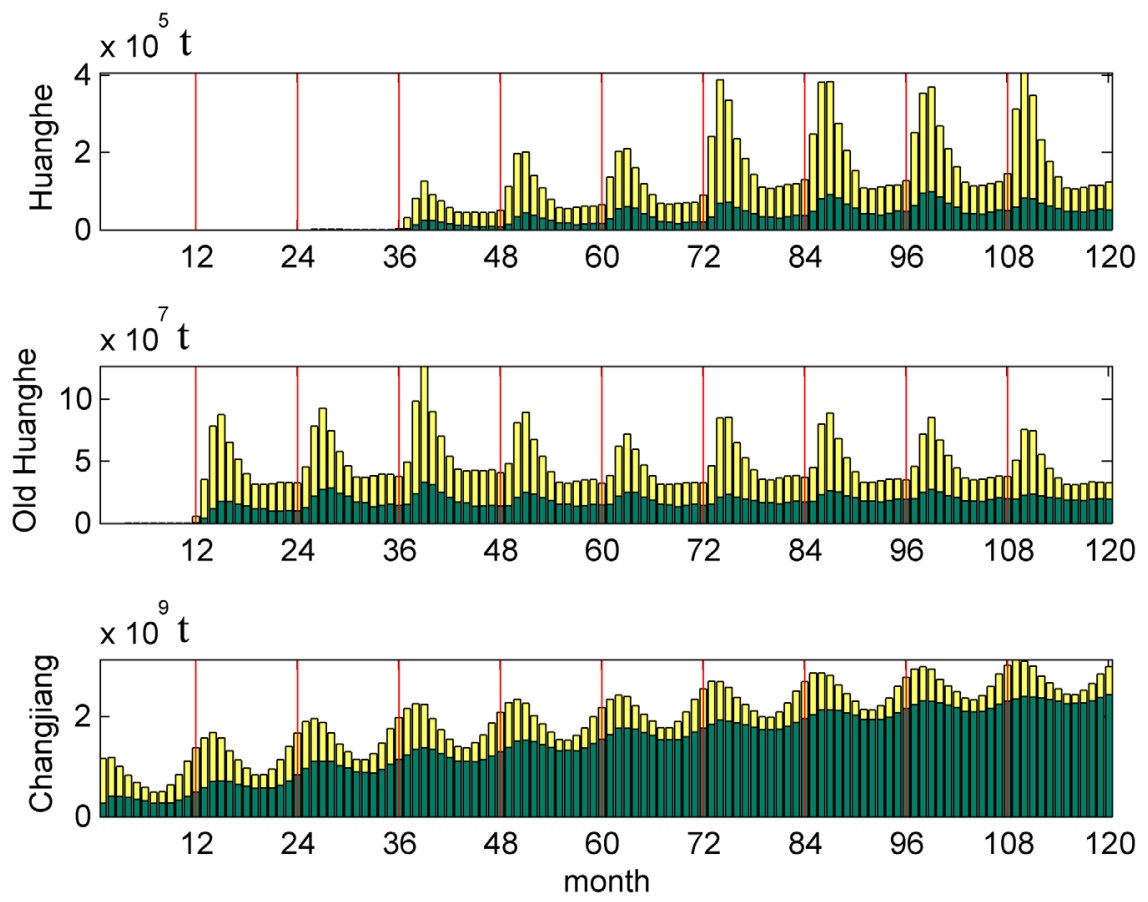

Figure 11. The Huanghe River, the Old Huanghe Delta and the Changjiang River discharged sediment mass ( $t$ ) that is deposited on the sea bed and suspended in the water column in region $\mathrm{C}$ of Figure 2 (the Zhejiang and Fujian provinces mud patch). The yellow represents suspended-sediment mass and the dark green represents deposited-sediment mass, both at the end of each month. Note: different mass scales are used for different plots.

After 10 years, about $5 \times 10^{7}$ t Changjiang River sediment is transported to the trough and $1.6 \times 10^{7} \mathrm{t}$ deposited there while $0.4 \times 10^{7}$ t Old Huanghe Delta sediment settles down there. The transport of the Huanghe River sediment to the trough is negligible.

[41] There is no clearly defined seasonal cycle in the transport of sediment to the Okinawa Trough and it seems that stochastic water exchanges between the outer continental shelf water and the Kuroshio Current water carry the shelf sediment to the trough. However, particularly large events in the model tend to occur in winter and spring (e.g. the months around 40th, 73rd, and 108th). The analysis of the modeled current field and sediment transport results in the 40th, 73rd, and 108th months shows that: (1) the Taiwan Warm Current which flows to the outer shelf directly transports the Taiwan Strait sediment to the Okinawa Trough; (2) the Yellow Sea Coastal Current transports the coastal sediment to the south of Cheju Island and the water exchange between the outer shelf and the Kuroshio Current transports the sediment to the Okinawa Trough. The mechanisms which lead to the episodic sediment transport to the Okinawa Trough are unclear and it may be caused by the model artifact, which still needs further study.

\section{Discussion}

[42] Even though only three sediment classes are considered and the parameters (Table 1) used in this study are rather uncertain, the sediment transport in the BYECS appears to be generally well simulated. The sources of the fine-grain sediment in the outer sea mud patches are identi- fied by the sediment transport path and the sediment mass transfer to the bed. The seasonal variation of the sediment transport to the mud patches in the BYECS has also been studied. Most important, some sediment transport processes that were not noted in previous studies are revealed by the model. For example, the traditional view is that the Taiwan Warm Current blocks the seaward sediment transport, but the model results show that the seaward branch of the Taiwan Warm Current carries the coastal sediment to the outer continental shelf area. This new view provides specific directions of investigation for future observation studies.

[43] There are also some limitations in our study. The simulated tidal amplitude is about $10 \%$ higher than observed, which will undoubtedly influence the modeled sediment transport to some extent. In addition, climatological wind forcing is used to force the model so the influence of strong winter storms and typhoons on sediment transport is not represented and there is no river input to the model. Due to the simplification of the sediment parameters in the sediment model, the modeled sediment transport fluxes and deposition rates can only be considered indicative. Also, the seasonal variability and deposition mechanisms governing the mud patch southwest of Cheju Island and offshore from the Zhejiang and Fujian provinces are not reproduced accurately.

[44] Therefore, more accurate forcing, more realistic initial sediment conditions, more sediment classes and more precise sediment parameters are needed in future model simulations to get a more quantitative picture of sediment transport in the BYECS. More long-term field observations in the continental shelf areas are also needed for the model calibration and testing. 

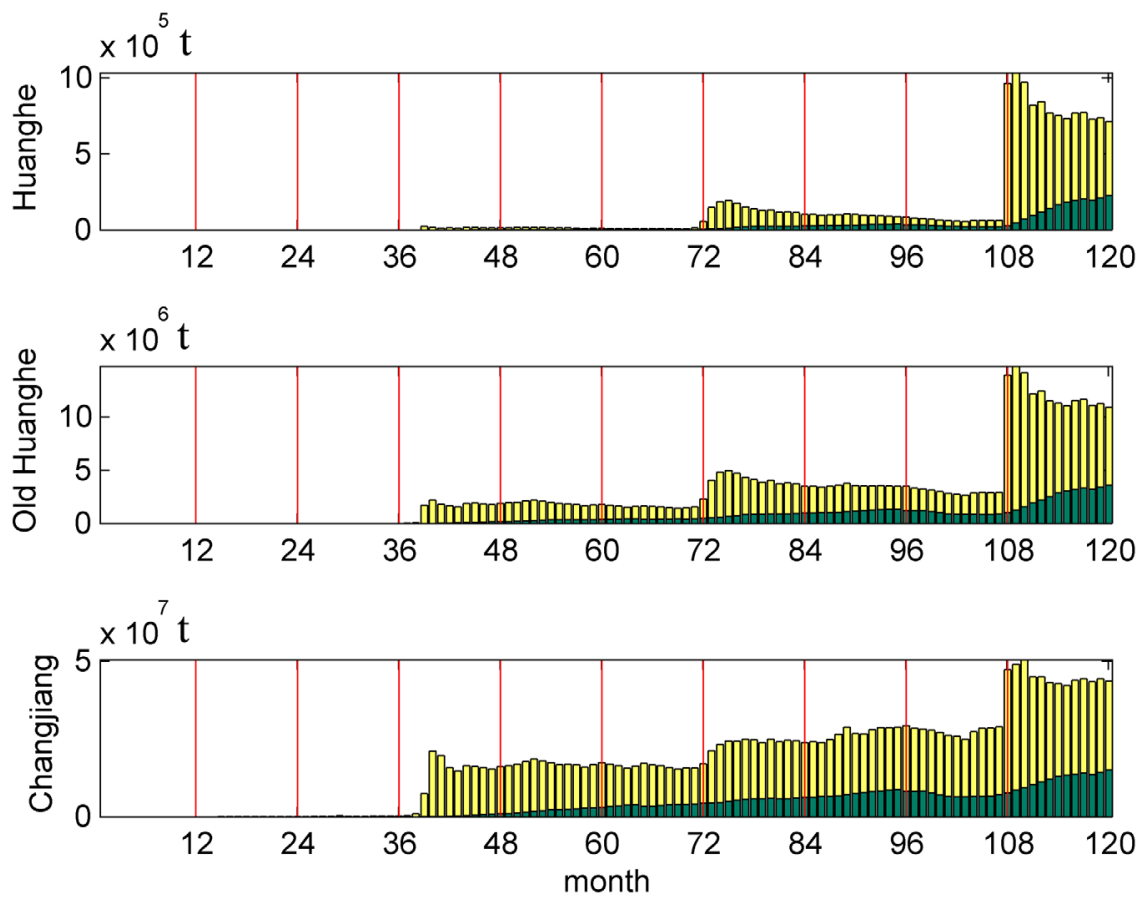

Figure 12. The Huanghe River, the Old Huanghe Delta and the Changjiang River discharged sediment mass ( $\mathrm{t}$ ) that is deposited on the sea bed and suspended in the water column in region D of Figure 2 (the Okinawa Trough mud patch). The yellow represents suspended-sediment mass and the dark green represents deposited-sediment mass. Note: different mass scales are used for different plots.

\section{Conclusion}

[45] In this paper, the Chinese mainland-derived fine-grain sediment transport is studied using the ROMS model taking into account the influence of currents, tides, and waves on the sediment transport. The basic current features in the BYECS are well represented by this model despite the lack of river inflow and episodic events in the model forcing. The distribution of deposited-sediment indicates that the Huanghe River sediment can be transported to the Yellow Sea by the Bohai Sea Coastal Current in winter, but little makes it to the outer continental shelf. The Old Huanghe Delta sediment is transported to the Yellow Sea Trough by the Yellow Sea Warm Current or is transported to the Sea of Japan by the Tsushima Warm Current in summer. The Changjiang River sediment is mainly transported to the mud patch off the coast of the Zhejiang and Fujian provinces in winter and spring; afterward the Taiwan Warm Current takes this sediment to the outer continental shelf of the East China Sea instead of blocking the seaward sediment transport as in the traditional view. Due to the unfavorable depositional environment for the fine-grain sediment in the model, most of the outer shelf Changjiang River sediment keeps moving to the Yellow Sea Trough and the Sea of Japan instead of depositing over the Cheju Island mud patch area, a topic that needs further study. Land-derived sediment cannot be easily transported to the Okinawa Trough under normal conditions, but the Taiwan Warm Current and the episodic water exchange between the outer continental shelf and the Kuroshio Current can carry a small amount of the Changjiang River and Old Huanghe Delta sediment to the Okinawa Trough. The transport of the Huanghe River sediment to the Okinawa Trough is negligible.
[46] Acknowledgments. We sincerely express our thanks to the developers of the ROMS model. This paper is supported by National Basic Research Program of China (973 Program 2010CB428904), Fundamental Research Funds for the Central Universities (201313037), and China Scholarship Council. CB also thanks the GEOMAR |Helmholtz Centre for Ocean Research Kiel for hospitality during an 18 month visit and for the provision of computing facilities during the time this work was carried out. RJG is grateful for continuing support from GEOMAR. Helpful comments and suggestions provided by two anonymous reviewers are greatly appreciated.

\section{References}

Adams, C. E., and G. L. Weatherly (1981), Some effects of suspended sediment stratification on an oceanic bottom boundary layer, J. Geophys. Res., 86(C5), 4161-4172, doi:10.1029/JC086iC05p04161.

Alexander, C. R., D. J. DeMaster, and C. A. Nittrouer (1991), Sediment accumulation in a modern epicontinental-shelf setting: The Yellow Sea, Mar. Geol., 98(1), 51-72, doi:10.1016/0025-3227(91)90035-3.

Antonov, J. I., R. A. Locarnini, T. P. Boyer, A. V. Mishonov, and H. E. Garcia (2006), World Ocean Atlas 2005 Volume 2: Salinity, in: NOAA Atlas NESDIS, edited by H. E. Garcia, and S. Levitus, p. 182, NOAA, Washington, D. C.

Aoki, S., K. Oinuma, and T. Sudo (1974), The distribution of clay minerals in the recent sediments of the Japan Sea, Deep Sea Res. Oceanogr. Abstr., 21(4), 299-310, doi:10.1016/0011-7471(74)90101-6.

Bao, X. W., Z. Li, Y. Z. Wang, and N. Li (2010), Sediment distribution features in the North Yellow Sea during summer and winter, J. Sediment Res., 2, 48-56.

Bi, N., Z. Yang, H. Wang, D. Fan, X. Sun, and K. Lei (2011), Seasonal variation of suspended-sediment transport through the southern Bohai Strait, Estuarine Coastal. Shelf Sci., 93(3), 239-247, doi:10.1016/ j.ecss.2011.03.007.

Bian, C. W., W. S. Jiang, and D. H. Song (2010), Terrigenous transportation to the Okinawa Trough and the influence of typhoons on suspended sediment concentration, Cont. Shelf Res., 30(10-11), 1189-1199, doi:10.1016/j.csr.2010.03.008.

Bian, C. W., W. S. Jiang, Q. Quan, T. Wang, R. J. Greatbatch, and W. Li (2013a), Distributions of suspended sediment concentration in the 
Yellow Sea and the East China Sea based on field surveys during the four seasons of 2011, J. Mar. Syst., 121-122, 24-35, doi:10.1016/ j.jmarsys.2013.03.013.

Bian, C. W., W. S. Jiang, R. Greatbatch, and H. Ding (2013b), The suspended sediment concentration distribution in the Bohai Sea, Yellow Sea and East China Sea, J. Ocean Univ. China, 12(3), 345-354, doi:10.1007/s11802-013-1916-3.

Booij, N., R. C. Ris, and L. H. Holthuijsen (1999), A third-generation wave model for coastal regions 1 . Model description and validation, J. Geophys. Res., 104(C4), 7649-7666, doi:10.1029/98JC02622.

Bornhold, B., Z. Yang, G. Keller, D. Prior, W. Wiseman, Q. Wang, L. Wright, W. Xu, and Z. Zhuang (1986), Sedimentary framework of the modern Huanghe (Yellow River) delta, Geo Mar. Lett., 6(2), 77-83, doi: 10.1007/BF02281643.

Byun, D., and X. H. Wang (2005), The effect of sediment stratification on tidal dynamics and sediment transport patterns, J. Geophys. Res., 110, C3011, doi:10.1029/2004JC002459.

Cai, D. L., X. F. Shi, W. J. Zhou, W. G. Liu, S. F. Zhang, Y. N. Cao, and Y. B. Han (2001), Sources and transport of suspended matter and sediments in the southern Yellow Sea: Evidence from stable carbon isotopic composition, Chin. Sci. Bull. (S1), 563-570.

Carton, J. A., and B. S. Giese (2008), A reanalysis of ocean climate using simple ocean data assimilation (SODA), Mon. Weather Rev., 136, 29993017, doi:10.1175/2007MWR1978.1

Chung, Y., and W. C. Chang (1995), Pb-210 fluxes and sedimentation rates on the lower continental slope between Taiwan and the South Okinawa Trough, Cont. Shelf Res., 15(2-3), 149-164, doi:10.1016/02784343(94)E0023-F.

Condie, S. A., and C. R. Sherwood (2006), Sediment distribution and transport across the continental shelf and slope under idealized wind forcing, Prog. Oceanogr., 70(2-4), 255-270, doi:10.1016/j.pocean.2005.07.003.

Condie, S. A., M. Herzfeld, N. Margvelashvili, and J. R. Andrewartha (2009), Modeling the physical and biogeochemical response of a marine shelf system to a tropical cyclone, Geophys. Res. Lett., 36, L22603, doi:10.1029/2009GL039563.

DaSilva, A., A. C. Young, and S. Levitus (1994), Atlas of Surface Marine Data 1994, Volume 1: Algorithms and Procedures, in: NOAA Atlas NESDIS 6, edited by S. Levitus, US Dep. of Commer. NOAA NESDIS, Seabrook, Md.

DeMaster, D. J., B. A. McKee, C. A. Nittrouer, J. Qian, and G. Cheng (1985), Rates of sediment accumulation and particle reworking based on radiochemical measurements from continental shelf deposits in the East China Sea, Cont. Shelf Res., 4(1-2), 143-158, doi:10.1016/02784343(85)90026-3.

Dong, L., J. Su, and K. Wang (1989), The relationship of the tidal current and the sediment transport in the Bohai Sea and the Yellow Sea, Acta Oceanol. Sin., 11(1), 102-114.

Du, R. Z., G. X. Liu, S. L. Yang, Y. H. Zhou, and B. Zhang (1990), Modern sedimentation rate and sedimentation process in Bohai Sea, Mar. Geol. Quat. Geol., 10(03), 15-22.

Egbert, G. D., and S. Y. Erofeeva (2002), Efficient inverse modeling of barotropic ocean tides, J. Atmos. Oceanic Technol., 19(2), 183-204, doi:10.1175/1520-0426(2002)019<0183:EIMOBO>2.0.CO;2.

Emery, K. O. (1968), Relict sediments on continental shelves of world, Am. Assoc. Pet. Geol. Bull., 52(3), 445-464.

Griffies, S. M., et al. (2009), Coordinated ocean-ice reference experiments (COREs), Ocean Modell., 26(1-2), 1-46, doi:10.1016/j.ocemod 2008.08.007

Guan, B. X. (1994), Patterns and structures of the currents in Bohai Huanghai and East China Sea, in Oceanology of China Seas, edited by D. Zhou, Y. B. Liang, and C. K. Zeng, pp. 17-26, Kluwer Acad., Dordrecht, Netherlands.

Guo, B. H., K. Lin, and H. B. Zuo (1987), Some features on the circulation in the East China Sea, in Collected Papers on Kuroshio Survey and Study, edited by X. P. Sun, pp. 15-32, China Ocean Press, Beijing.

Guo, Z., Z. Yang, D. Zhang, D. J. Fan, and K. Lei (2002), Seasonal distribution of suspended matter in the northern East China Sea and barrier effect of current circulation on its transport, Acta Oceanol. Sin., 24(5), 71-80.

Hong, G. H., S. H. Kim, C. S. Chung, D. J. Kang, D. H. Shin, H. J. Lee, and S. J. Han (1997), 210Pb-derived sediment accumulation rates in the southwestern East Sea (Sea of Japan), Geo Mar. Lett., 17(2), 126-132, doi: $10.1007 / \mathrm{s} 003670050017$.

Hu, D. (1984), Upwelling and sedimentation dynamics, Chin. J. Oceanol. Limnol., 2, 12-19, doi:10.1007/BF02888388.
Hu, D. (1995), The role of vertical circulation in sediment dynamics, in China Contribution to Global Change Studies, edited by Y. Duzheng and L. Hai, pp. 168-170, China Science Press, Beijing.

Huang, H., F. Li, and X. Zhang (2001), A primary comparison of water and sediment flux between the Changjiang river and the Yellow river, in Land-Sea Interactions in Changjiang and Zhujiang Estuaries and Adjacent Waters, edited by D. X. Hu, W. Y. Zhang, and S. Zhang, pp. 36-49, China Ocean Press, Beijing.

Huh C., and C. Su (1999), Sedimentation dynamics in the East China Sea elucidated from ${ }^{210} \mathrm{~Pb},{ }^{137} \mathrm{Cs}$ and ${ }^{239,240} \mathrm{Pu}$, Mar. Geol., 160, 183-196, doi: 10.1016/S0025-3227(99)00020-1.

Huh, C., C. Su, C. Wang, S. Lee, and I. Lin (2006), Sedimentation in the Southern Okinawa trough-Rates, turbidites and a sediment budget, Mar. Geol., 231, 129-139.

Lan, X. H., H. X. Wang, R. H. Li, Z. H. Lin, and Z. X. Zhang (2007), Major elements composition and provenance analysis in the sediments of the South Yellow Sea, Earth Sci. Frontiers, 14(4), 197-203.

Lan, X. H., X. J. Zhang, G. T. Zhao, and Z. X. Zhang (2009), Distributions of rare earth elements in sediments from Core NT1 of the South Yellow Sea and their provenance discrimination, Geochimica, 38(2), 123-132.

Large, W., and S. Yeager (2009), The global climatology of an interannually varying air-sea flux data set, Clim. Dyn., 33, 341-364, doi:10.1007/ s00382-008-0441-3.

Larsen, L. H., G. A. Cannon, and B. H. Choi (1985), East China Sea tide currents, Cont. Shelf Res., 4(1-2), 77-103, doi:10.1016/02784343(85)90023-8.

Lee, H. J., and S. K. Chough (1989), Sediment distribution, dispersal and budget in the Yellow Sea, Mar. Geol., 87(2-4), 195-205, doi:10.1016/ 0025-3227(89)90061-3.

Li, F. Y., S. Gao, J. J. Jia, and Y. Y. Zhao (2002), Contemporary deposition rates of fine-grained sediment in the Bohai and Yellow Seas, Oceanol. Limnol. Sin., 33(4), 364-369.

Li, F. Y., Y. L. Shi, L. J. He, F. Chen, and X. Q. Zhu (1999), Relationship between the variations in sedimentation rates and sedimentation environments in the Okinawa trough since the late Pleistocene, Oceanol. Limnol. Sin., 30(5), 540-545.

Li, G., H. Wang, and H. Liao (2010), Numerical simulation on seasonal transport variations and mechanisms of suspended sediment discharged from the Yellow River to the Bohai Sea, J. Geogr. Sci., 20, 923-937, doi: 10.1007/s11442-010-0821-6.

Li, J. (2007), Spatial and temporal variation of the sedimentation rates in Okinawa trough since the late Pleistocene and their controlling factors, Mar. Geol. Quat. Geol., 27(4), 37-43.

Li, P. Y., Y. J. Wang, and Z. X. Liu (1999), Formation age and sedimentation rates in Okinawa trough, Sci. China (Series D), 29(01), 50-55.

Li, W. R., Y. T. Guan, Z. S. Yang, L. H. Cao, Q. Wang, Y. J. Wang, and X. R. Wang (1999), Study on hazardous characteristics of turbid flow in Okinawa trough, J. Nat. Disasters, 8(3), 98-102.

Li, W. R., Z. S. Yang, Q. Wang, L. H. Cao, Y. J. Wang, and X. R. Wang (2001), Terrigenous transportation through canyon and sedimentation of submarine fan in the Okinawa, Oceanol. Limnol. Sin., 32(04), 371-380.

Lim, D., J. Choi, H. Jung, K. Rho, and K. Ahn (2007), Recent sediment accumulation and origin of shelf mud deposits in the Yellow and East China Seas, Prog. Oceanogr., 73(2), 145-159.

Lin, X. T., S. J. Du, and W. R. Li (2003), Zonation of detrital sediments distribution on the outer East China Sea-determined by using BP artificial neural network analysis, Mar. Sci., 27(11), 75-80.

Lin, X., J. Yang, J. Guo, Z. Zhang, Y. Yin, X. Song, and X. Zhang (2011), An asymmetric upwind flow, Yellow Sea Warm Current: 1. New observations in the western Yellow Sea, J. Geophys. Res., 116, C04026, doi: 10.1029/2010JC006513.

Liu, B. H., X. S. Li, Y. X. Zhao, Y. P. Zheng, and J. L. Wu (2005), Debris transport on the western continental slope of the Okinawa trough: Slumping and gravity flowing, Oceanol. Limnol. Sin., 36(1), 1-9.

Liu, J., J. D. Milliman, and S. Gao (2002), The Shandong mud wedge and post-glacial sediment accumulation in the Yellow Sea, Geo Mar. Lett., 21(4), 212-218, doi:10.1007/s00367-001-0083-5.

Liu, J., K. Xu, A. Li, J. D. Milliman, D. M. Velozzi, S. Xiao, and Z. Yang (2007), Flux and fate of Yangtze River sediment delivered to the East China Sea, Geomorphology, 85(3-4), 208-224, doi:10.1016/j.geomorph. 2006.03.023.

Liu, Z., and D. Hu (2009), Preliminary study on the Huanghai Sea coastal current and its relationship with local wind in summer, Acta Oceanol. Sin., 31(2), 1-7. 
Lu, J., F. Qiao, X. Wang, Y. Wang, Y. Teng, and C. Xia (2011), A numerical study of transport dynamics and seasonal variability of the Yellow River sediment in the Bohai and Yellow seas, Estuarine Coastal Shelf Sci., 95(1), 39-51, doi:10.1016/j.ecss.2011.08.001.

Martin, J. M., J. Zhang, M. C. Shi, and Q. Zhou (1993), Actual flux of the Huanghe (yellow river) sediment to the Western Pacific ocean, Neth. J. Sea Res., 31(3), 243-254, doi:10.1016/0077-7579(93)90025-N.

Meade, R. H. (1996), River-sediment inputs to major deltas, in Sea-Level Rise and Coastal Subsidence, Coastal Systems and Continental Margins, edited by J. D. Milliman and B. Haq, pp. 63-85, Springer, Houten, Netherlands, doi:10.1007/978-94-015-8719-8_4.

Mehta, J. A., and W. H. McAnally (2008), Fine-grained sediment transport, in Sedimentation Engineering: Processes, Measurements, Modeling, and Practice, edited by M. H. Garcia, Am. Soc. of Civil Eng., Reston, $\mathrm{Va}$.

Mellor, G. L., and T. Yamada (1982), Development of a turbulence closure model for geophysical fluid problems, Rev. Geophys. Space Phys., 20, 851-875, doi:10.1029/RG020i004p00851.

Milliman, J. D., and R. H. Meade (1983), World-wide delivery of river sediment to the oceans, J. Geol., 91(1), 1-21.

Milliman, J. D., R. C. Beardsley, Z. Yang, and R. Limeburner (1985b), Modern Huanghe-derived muds on the outer shelf of the East China Sea: Identification and potential transport mechanisms, Cont. Shelf Res., 4(12), 175-188, doi:10.1016/0278-4343(85)90028-7.

Milliman, J. D., S. Huang-ting, Y. Zuo-sheng, and R. H. Mead (1985a), Transport and deposition of river sediment in the Changjiang estuary and adjacent continental shelf, Cont. Shelf Res., 4(1-2), 37-45, doi:10.1016/ 0278-4343(85)90020-2.

Milliman, J. D., L. Fan, Z. Yiyang, Z. Tiemin, and R. Limeburner (1986), Suspended matter regime in the Yellow Sea, Prog. Oceanogr., 17(3-4), 215-227, doi:10.1016/0079-6611(86)90045-5.

Milliman, J. D., Y. Qin, and Y. Park (1989), Sediments and sedimentary processes in the Yellow and East China Seas, in Sedimentary Facies in the Active Plate Margin, edited by A. Taira and F. Masuda, pp. 233-249, Terra Sci., Tokyo.

Otosaka, S., O. Togawa, M. Baba, E. Karasev, Y. N. Volkov, N. Omata, and S. Noriki (2004), Lithogenic flux in the Japan Sea measured with sediment traps, Mar. Chem., 91(1-4), 143-163, doi:10.1016/ j.marchem.2004.06.006.

Pan, Y. Q., J. L. Su, and D. R. Xu (1987a), Oceanographic conditions of Taiwan warm current area during December 1984-January 1985, in Collected Papers on Kuroshio Survey and Study, pp. 149-162, China Ocean Press, Beijing.

Pan, Y. Q., J. L. Su, and D. R. Xu (1987b), Oceanographic conditions of Taiwan warm current area during June-July 1984, in Collected Papers on Kuroshio Survey and Study, pp. 118-132, China Ocean Press, Beijing.

Pang, C., and D. Hu (2002), Upwelling and sedimentation dynamics III: Coincidence of upwelling areas with mud patches in north hemisphere shelf seas, Chin. J. Oceanol. Limnol., 20, 101-106, doi:10.1007/ BF02849645.

Pang, C., X. Bai, and D. Hu (2004), The transport and sedimentation of suspended matter and their seasonal variation are affected by circulation and tide current in the Bohai Sea, the Yellow Sea and the East China Sea, Stud. Mar. Sin., 46, 32-41.

Peng, M., and D. Hu (1997), Outflow of suspended materials from the Changjiang river mouth, Chin. J. Oceanol. Limnol., 15(03), 258-263.

Qi, J., F. Y. Li, J. M. Song, S. Gao, G. Z. Wang, and P. Cheng (2004), Sedimentation rate and flux of the north Yellow Sea, Mar. Geol. Quat. Geol., 24(2), 9-14.

Qin, Y. S., and F. Li (1986), The influence of Yellow River sediment into the sea on sedimentation in Bohai and Huanghai seas, Stud. Mar. Sin., 27, 124-134.

Qu, T., and D. Hu (1993), Upwelling and sedimentation dynamics, Chin. J. Oceanol. Limnol., 11, 289-295, doi:10.1007/BF02850633.

Saito, Y., and Z. S. Yang (1995), Historical change of the Huanghe (Yellow River) and its impact on the sediment budget of the East China Sea, in Global Fluxes of Carbon and its Related Substance in the Coastal SeaOcean-Atmosphere System, edited by S. Tsunogai et al., pp. 7-12, M \& J Int., Yokohama, Japan.

Sternberg, R. W., L. H. Larsen, and Y. T. Miao (1985), Tidally driven sediment transport on the East China Sea continental shelf, Cont. Shelf Res., 4(1-2), 105-120, doi:10.1016/0278-4343(85)90024-X.
Sun, X. G., M. Fang, and W. Huang (2000), Spatial and temporal variations in suspended particulate matter transport on the Yellow and East China Sea shelf, Oceanol. Limnol. Sin., 31(6), 581-587.

Takikawa, T., J. Yoon, and K. Cho (2005), The Tsushima warm current through Tsushima straits estimated from ferryboat ADCP data, J. Phys. Oceanogr., 35, 1154-1168, doi:10.1175/JPO2742.1.

Tang, Y. X., E. M. Zou, H. Lie, and J. Lie (2000), Some features of circulation in the southern Huanghai Sea, Acta Oceanol. Sin., 22(1), 1-16.

Teague, W. J., and G. A. Jacobs (2000), Current observations on the development of the Yellow Sea Warm Current, J. Geophys. Res., 105(C2), 3401-3411, doi:10.1029/1999JC900301.

Wang, F., H. Wang, J. F. Li, Y. D. Pei, C. F. Fan, and Z. W. Shang (2006), Current study of $210 \mathrm{~Pb}$ and $137 \mathrm{Cs}$ geochronology in the circum-Bohai Sea region, Geol. Rev., 52(2), 244-250.

Wang, K. S., X. F. Shi, and X. L. Jiang (2001), Sources and partition of the South Yellow Sea sediments: Evidence from light mineral, Chin. Sci. Bull., (S1), 24-29.

Wang, L., X. Chen, and T. Chu (1997), A contrast analysis on the loads character of the Changjiang River and the Yellow River, Geogr. Res., 16(4), 71-79.

Wang, W., and W. Jiang (2008), Study on the seasonal variation of the suspended sediment distribution and transportation in the East China Seas based on SeaWiFS Data, J. Ocean Univ. China, 7(4), 385-392.

Wang, X. H. (2002), Tide-induced sediment resuspension and the bottom boundary layer in an idealized estuary with a muddy bed, J. Phys. Oceanogr., 32(11), 3113-3131, doi:10.1175/1520-0485(2002)032<3113: TISRAT $>2.0 . \mathrm{CO} ; 2$.

Wang, Y., and W. Jiang (2007), Numerical simulation of variations in winter and summer suspended material concentrations in the Bohai Sea, Yellow Sea and East China Sea, Adv. Mar. Sci., 25(1), 28-33, doi:16716647(2007)01-0028-06.

Warner, J. C., C. R. Sherwood, R. P. Signell, C. K. Harris, and H. G. Arango (2008), Development of a three-dimensional, regional, coupled wave, current, and sediment-transport model, Comput. Geosci., 34(10), 1284-1306, doi:10.1016/j.cageo.2008.02.012.

Wei, J. W., X. F. Shi, C. Y. Xin, and H. P. Zhang (2001), The mineral distribution of the South Yellow Sea clay and its implications, Chin. Sci. Bull., 46(S1), 30-33.

Xu, K., A. Li, J. P. Liu, J. D. Milliman, Z. Yang, C. Liu, S. Kao, S. Wan, and F. Xu (2012), Provenance, structure, and formation of the mud wedge along inner continental shelf of the East China Sea: A synthesis of the Yangtze dispersal system, Mar. Geol., 291-294, 176-191, doi:10.1016/j.margeo.2011.06.003.

Yanagi, T., and K. Inoue (1995), A numerical experiment on the sedimentation processes in the Yellow Sea and the East China Sea, J. Oceanogr., 51, 537-552, doi:10.1007/BF02270523.

Yanagi, T., T. Shimizu, and T. Matsuno (1996), Baroclinic eddies south of Cheju Island in the East China Sea, J. Oceanogr., 52, 763-769, doi: 10.1007/BF02239464.

Yang, Z., and J. Liu (2007), A unique Yellow River-derived distal subaqueous delta in the Yellow Sea, Mar. Geol., 240(1-4), 169-176, doi:10.1016/j.margeo.2007.02.008.

Yang, Z., Z. Guo, Z. Wang, J. Xu, and W. Gao (1992), Basic pattern of transport of suspended matter from the Yellow Sea and East China Sea to the eastern deep seas, Acta Oceanol. Sin., 14(2), 81-90.

Yang, Z., K. Lei, Z. Guo, and H. Wang (2007), Effect of a winter storm on sediment transport and resuspension in the distal mud area, the East China Sea, J. Coastal Res., 232(2), 310-318, doi:10.2112/03-0130.1.

Yuan, D., J. Zhu, C. Li, and D. Hu (2008a), Cross-shelf circulation in the Yellow and East China Seas indicated by MODIS satellite observations, J. Mar. Syst., 70, 134-149, doi:10.1016/j.jmarsys. 2007.04.002.

Yuan, Y. R., G. Q. Chen, W. D. Yang, and C. W. Zhu (1987), The characteristics of Okinawa trough sediments, Acta Oceanol. Sin., 9(3), 353-359.

Yuan, Y., H. Wei, L. Zhao, and W. Jiang (2008b), Observations of sediment resuspension and settling off the mouth of Jiaozhou Bay, Yellow Sea, Cont. Shelf Res., 28(19), 2630-2643, doi:10.1016/ j.csr.2008.08.005.

Zhao, Y. Y., F. Y. Li, D. J. DeMaster, C. A. Nittrouer, and J. D. Milliman (1991), Preliminary studies on sedimentation rate and sediment flux of the south Huanghai Sea, Oceanol. Limnol. Sin., 22(1), 38-43.

Zhu, Y., and R. Chang (2000), Preliminary study of the dynamic origin of the distribution pattern of bottom sediments on the continental shelves of the Bohai Sea, Yellow Sea and East China Sea, Estuarine Coastal Shelf Sci., 51(5), 663-680, doi:10.1006/ecss.2000.0696. 